\title{
Interaction between smectite and bacteria: Implications for bentonite as backfill material in the disposal of nuclear waste
}

\author{
Julia N. Perdrial ${ }^{\mathrm{a}, *}$, Laurence N. Warr ${ }^{\mathrm{b}}$, Nicolas Perdrial ${ }^{\mathrm{c}}$, Marie-Claire Lett ${ }^{\mathrm{d}}$, Francoise Elsass ${ }^{\mathrm{e}}$ \\ a Centre de Géochimie de la Surface, UMR-7517 CNRS and Université Louis Pasteur, 1 rue Blessig, 67084- Strasbourg, France \\ ${ }^{\mathrm{b}}$ Institut für Geographie und Geologie, Ernst-Moritz-Arndt Universität, F. Ludwig-Jahn-Str. 17A, 17487-Greifswald, Germany \\ ' Department of Soil, Water and Environmental Science, University of Arizona, Tucson, AZ 85721, USA \\ ' Laboratoire Génétique Moléculaire, Génomique, Microbiologie, UMR 7156, ULP/ CNRS, 28, rue Goethe 67083-Strasbourg, France \\ e PESSAC, INRA, RD10 78026 Versailles Cedex, France
}

\section{A R T I C L E I N F O}

\section{Article history:}

Received 18 November 2008

Received in revised form 6 March 2009

Accepted 9 March 2009

Editor: J. Fein

\section{Keywords:}

MX80 bentonite

Nontronite

Shewanella putrefaciens

Confined volume

Backfill

Nuclear waste disposal

\begin{abstract}
A B S T R A C T
This study presents experimental results on the interaction between smectite clays (nontronite and MX80 bentonite) and the facultative anaerobic, heterotrophic Shewanella putrefaciens in two types of conditions: i) batch experiments with low solid to liquid ratios and agitated oxygenated conditions and ii) reaction-cell experiments with high solid to liquid ratios in anaerobic, confined volume conditions. The former was chosen to study the ability of S. putrefaciens to live on smectite as the only substrate and the latter was designed to simulate more compacted subsurface environments of underground repository waste sites. Bacterial cell counts in the batch experiments reveal the prolonged survival of $S$. putrefaciens in the smectite suspension compared to standard laboratory culture media. In the case of nontronite, variations in solution chemistry indicate bacterial consumption and/or partial binding of cations. Microscopic investigations show associated biofilm-smectite aggregates and Si-rich gels produced by the partial dissolution of clay mineral grains. In contrast, the MX80 bentonite was not seen to be chemically affected by bacterial activity in batch cultures. However, the confined volume experiments, using reaction-cell X-ray diffraction combined with peak calculations (CALCMIX), do indicate that $S$. putrefaciens has a pronounced effect on the water content of compacted MX80 bentonite. The presence of these bacteria enhances both the amount of adsorbed interlayer water and the available pore space. The anaerobic conditions were also favourable for accessory phase dissolution (notably calcite) and synchronous precipitation of lepidocrocite related to bacterially induced changes in $\mathrm{pH}$ and Eh. The varied response of the two studied clays to the presence of bacteria is attributed largely to the materials composition. The interlayer $\mathrm{Ca}$ of nontronite facilitates bacterial attachment to surfaces and $\mathrm{Fe}$ (III) provokes the production of chelators that enhance mineral dissolution. Although MX80 bentonite is less affected by bacterially enhanced dissolution, it is more sensitive to microstructural changes. Mechanisms involve aggregation of Na-smectite particles in voids created by cell lyses, the initial production of biofilm and the $\mathrm{pH}$ and Eh dependent dissolution and precipitation of accessory minerals. This investigation highlights the importance of including bacteria-mineral studies in assessing the safety issue of underground disposal of nuclear waste material.
\end{abstract}

(c) 2009 Elsevier B.V. All rights reserved.

\section{Introduction}

The complex interaction of fine-grained minerals and bacteria in soils and sediments has gained increasing attention over the last few decades. Synergistic effects are evident from the fact that bacteria can have pronounced effects on both mineral growth (Gorshkov et al., 1992; Kohler et al., 1994; Ehrlich, 1999; Kawano and Tomita, 2001) and dissolution (Bennett et al., 1996; Liermann et al., 2000; Rosenberg and Maurice, 2003; O'Reilly et al., 2006). When subjected to nutrientpoor (starvation) conditions, bacteria exhibit numerous strategies to

\footnotetext{
* Corresponding author. CGS, 1 rue Blessig, 67084 Strasbourg Cedex, France. Fax: +33 390240402.

E-mail address: J.N.Perdrial@email.de (J.N. Perdrial).
}

accumulate nutrients such as the production of high affinity chelators (Hersman et al., 2000) or the systematic adhesion to surfaces (Dawson et al., 1981; Kjelleberg and Hermansson, 1984). Bacterial adherence is often facilitated by the excretion of exopolymeric substance (EPS; Van Loosdrecht et al., 1989; Omoike and Chorover, 2006): a process which is frequently associated with increasing alteration at the mineral interface (Marshall et al., 1971; Van Loosdrecht et al., 1990; Banfield and Welch, 2000; Maurice and Warren, 2006).

The effect of bacterial activity on oxyhydroxides and oxides of Mn and Fe (Myers and Nealson, 1988; Lovley et al., 1989; O'Loughlin et al., 2007), silicate weathering (Barker et al., 1997; Liermann et al., 2000; Bennett et al., 2001) and clay minerals reactions (Maurice et al., 2001; Kim et al., 2004; O'Reilly et al., 2006) has received particular attention. In a pioneering work on swelling clay minerals by Stotzky (1966a,b) and 
Stotzky and Rem (1966), montmorillonite was shown to stimulate bacterial respiration. More recently, the interaction between ferruginous smectites (nontronites) and metal reducing bacteria has received much attention (Stucki et al., 1987; Gates et al., 1998; Kostka et al., 1999; Kim et al., 2004). Under anaerobic conditions, Shewanella sp. were shown to diminish the hydration capacity of Fe-smectite by reduction of octahedral $\mathrm{Fe}$, leading to modification of charge distribution and possible fixation of K (Stucki et al., 1987; Wu et al., 1988; Lovley, 1991; Kostka et al., 1999; Kim et al., 2004; Stucki and Kostka, 2006).

Any reaction that leads to the reduction of the swelling capacity of smectite is of relevance when assessing the safety issue of clay sealants to be used in waste confinement. Such sealants, in the form of bentonite clays, are generally considered ideal because of their extensive adsorption capacity, large surface area (per g) and impermeable, selfsealing properties when hydrated (Hermann-Stengele and Plötze, 2000; Komine and Ogata, 2004; Pusch, 2006). As a result bentonite is proposed for the engineered backfill barrier in many planned underground nuclear waste repositories, to be used either in the form of compressed blocks of controlled dimension, density and composition (Johannesson et al., 1995) or as pellets or granules to fill in remaining cavities adjacent to the containers or host rock (Stroes-Gascoyne et al., 2008). As the main function of the engineered backfill is to inhibit or reduce ground water inflow that could corrode the containers and transport hazardous compounds to the biosphere (NEA, 1999; ANDRA, 2005; OECD, 2006), it is critical that the smectite remains chemically stable and maintains its full swelling and sealing capacity.

Because conditions in a repository site are generally expected to depress microbial activity with a lack of nutrients, water and restricted pore space in compacted bentonites, bacteria are generally not considered to play an important role in the backfill material (Pedersen, 2000; Pedersen et al., 2000). However, a selected group of microorganisms are expected to survive (Horn and Meike, 1995; Horn et al., 2004) and especially spore-forming organisms are likely to be present over significant periods of time (Chi Fru and Athar, 2008; StroesGascoyne et al., 2008). More extensive microbial activity will predictively characterize less densely packed interfacial environments and areas of disturbance, such as fractures and faults, where the bentonite barrier is disrupted, at least temporarily (Stroes-Gascoyne et al., 2008). As a result, the impact of such bacterial activity of the properties of the sealant smectite or related alteration products clearly requires consideration.

In this laboratory study of smectite-bacteria interaction we investigate two types of experimental systems relevant to underground waste disposal: i) The ability of the well studied bacteria, S. putrefaciens, to survive in smectite as the only substrate under dispersed, aerobic conditions similar to those of aqueous interfacial environments. ii) The effect of these bacteria on the sealing capacity of compacted smectite in experiments that serve as a more direct analogue for compacted backfill under anaerobic conditions. For this purpose a new type of flow-through reaction-cell was employed, that is mounted onto an X-ray diffractometer for in situ measurements of the state of compacted smectite hydration (Warr and Hofmann, 2003; Warr and Berger, 2007). Our results show that $S$. putrefaciens survival is aided by smectite and that the lack of nutrients and organic carbon is not a limiting factor in this system.

\section{Materials and methods}

\subsection{Material used in the study}

Two types of materials were studied: i) MX80 bentonite as original backfill material (ANDRA, 2005), which besides some accessory minerals is mostly composed of montmorillonite and ii) nontronite (Fe-rich smectite) simulating a Fe-rich alteration product. This material was chosen because thermochemical modeling and experiments showed that, amongst others, a Fe(II)-rich trioctahedral smectite may form in contact with the steel containers (Wilson et al., 2006a,b). Although dioctahedral Fe-rich smectite (nontronite) was not specifically detected in these experiments, we consider this material to be suitable to represent a Fe-rich swelling clay mineral. Both materials are obtainable from the manufacturer as untreated raw materials.

\subsubsection{Smectite and smectite-based materials: MX80 bentonite and nontronite}

MX80 is a commercial bentonite (CETCO, France) that was used without further purifying treatment. The interlayer sites of the montmorillonite are heteroionically occupied by Na and Ca according to the formula (Sauzeat et al., 2001):

$\mathrm{Na}_{0.18} \mathrm{Ca}_{0.11}\left[\mathrm{Al}_{1.52} \mathrm{Mg}_{0.26} \mathrm{Fe}_{0.17}^{(3+)}\right]\left[\mathrm{Si}_{3.96} \mathrm{Al}_{0.04}\right] \mathrm{O}_{10}(\mathrm{OH})_{2}$

Montmorillonite makes up around $76 \%$ of the raw material and the remaining fraction consists of mica, feldspar, quartz, calcite and pyrite (Table 1).

Nontronite fractions were prepared from samples obtained from the Clay Minerals Society (CMS). This nontronite (NAu-1) is a dioctahedral smectite that contains a high proportion of structural $\mathrm{Fe}$ (III) in the octahedral sites ( $34 \mathrm{wt} . \% \mathrm{Fe}_{2} \mathrm{O}_{3}$, Table 1$)$ and divalent $\mathrm{Ca}$ ions at interlayer sites. In order to homoionize the material, the nontronite was cation exchanged $\left(\mathrm{CaCl}_{2}\right)$ several times and then washed until no remaining salt could be detected (using the $\mathrm{AgNO}_{3}$ test). According to Keeling et al. (2000) the structural formula is:

$\mathrm{M}_{0.525}^{+}\left[\mathrm{Al}_{0.145} \mathrm{Fe}_{1.84} \mathrm{Mg}_{0.02}\right]\left[\mathrm{Si}_{3.49} \mathrm{Al}_{0.51}\right] \mathrm{O}_{10}(\mathrm{OH})_{2}$

As the raw powder contains impurities such as kaolinite, quartz, biotite and goethite, they were washed and a $\sim 93 \%$ pure $<0.5 \mu \mathrm{m}$

Table 1

Characteristics of the materials used in the experiments.

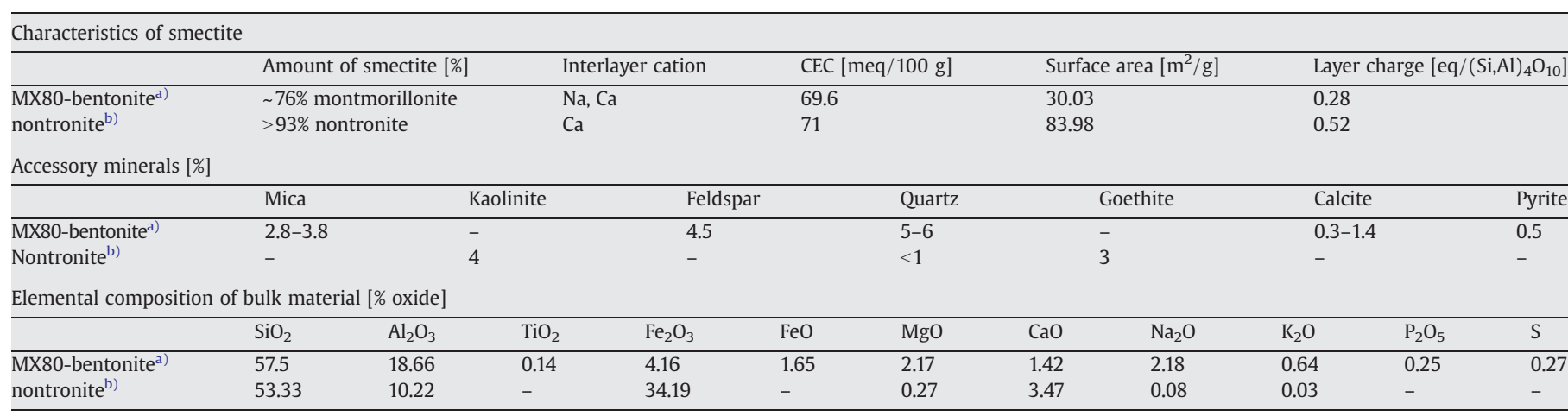

a) Data taken from Sauzeat et al. (2001).

b) Keeling et al. (2000). 
nontronite fraction separated by centrifugation (for remaining impurities, see Table 1).

\subsubsection{Shewanella putrefaciens}

S. putrefaciens are gram negative, heterotrophic bacteria which occur in a variety of aquatic and subsurface environments (Venkateswaran et al., 1999). As facultative anaerobes, they are able to use oxygen as a terminal electron acceptor (TEA) but under anaerobic conditions they can also use various acceptors such as nitrate, Mn(IV), Fe (III), U(V), fumarate or sulphite (Obuekwe and Westlake, 1982; DiChristina et al., 1988; Lovley et al., 1991).

Optimal growth conditions for the strain used in this study ( $S$. putrefaciens DMS 6067) are a temperature of around $25{ }^{\circ} \mathrm{C}$ and a near neutral $\mathrm{pH}(7)$. The bacteria were obtained from the "Deutsche Sammlung von Mikroorganismen und Zellkulturen" (DSMZ) and is identical with the American Type Culture Collection specification ATCC 8071. This strain had been formerly called Alteromonas putrefaciens (Lee et al., 1977; MacDonell and Colwell, 1985) but was re-classified (Gauthier et al.,1995). This particular species was chosen as a reference bacteria for this study because it is well studied and capable of respiring in both aerobic and anaerobic conditions (Kostka et al., 1996; Gates et al., 1998; Kim et al., 2004; Stucki and Kostka, 2006).

\subsubsection{Experimental solutions and growth media}

Incubation $(72 \mathrm{~h}$ ) of bacteria cultures prior to experimentation was made using a Luria Bertrani (LB) medium, whereas plate count testing of bacterial populations were undertaken on LB agar. A chemically defined minimal medium (M1; Myers and Nealson (1988)) was selected as the growth medium for reference experiments. For batch and confined volume experiments, autoclave sterilized Millipore ${ }^{\mathbb{C}}$ water $\left(121^{\circ} \mathrm{C}, 15 \mathrm{~min}\right)$ was employed as the standard aqueous solution.

\subsection{Experimental procedure}

\subsubsection{Batch solution experiments}

For batch experiments with nontronite and MX80 bentonite, the smectite was first sterilized $\left(110^{\circ} \mathrm{C}\right.$ for $3 \mathrm{~h}$ in the oven) and dispersed in sterile Millipore ${ }^{\odot}$ water (autoclave $121^{\circ} \mathrm{C}$ for $15 \mathrm{~min}$ ). The sterility of samples were tested on LB agar plates, however it cannot be excluded that microorganisms remained undetected by the method applied and that spore-forming organisms, that were seen to be abundant especially in MX80 (Chi Fru and Athar, 2008), may have survived. The term "sterile samples" is therefore used in this paper to indicate that no $S$. putrefaciens were added, as opposed to the term "bacteriacontaining" for samples, where the bacteria were introduced.

The bacteria cultures were grown in LB medium and washed with pure water ( 3 washings by centrifugation $4000 \mathrm{rpm} / 10 \mathrm{~min}$ ). A portion of sterilized smectite was suspended in Millipore water $(0.01$ and $0.04 \mathrm{~g} / \mathrm{ml}$ ) and treated with ultrasound (30 $\mathrm{min}$ ) in order to obtain a homogeneous suspension. Washed bacterial cultures were added after the ultrasound treatment, in order to not harm the cells, and the suspensions were then continuously agitated. The starting cell content yielded was around 5E04CFU $/ \mathrm{ml}$. Simultaneously, abiotic control experiments were prepared for comparison. Smectite_bacterial suspensions were sampled at selected intervals for ICP-OES (Inductively Coupled Plasma-Optical Emission Spectroscopy) analysis using a sterile syringe. The extracted samples were filtered using a $0.2 \mu \mathrm{m}$ polycarbonate membrane, acidified with concentrated $\mathrm{HNO}_{3}$, and stored in a dark cool place prior to analysis. As colloidal clay particles are not always retained by the filters, these may have a minor influence on the solution chemistry measurements made. Elemental concentrations ( $\mathrm{Al}, \mathrm{Si}, \mathrm{Mg}, \mathrm{Na}, \mathrm{K}$, Fe and $\mathrm{Ca}$ ) of elute solutions were obtained by ICP-OES using the "Plasma 400" of Perkin-Elmer.

Bacterial density was determined by viable cell counts and expressed as an increase in "colony forming units" (CFU) per ml. Samples were diluted by serial dilutions before being tested on agar plates. Colonies were grown by spreading $0.1 \mathrm{ml}$ of sample-suspension onto an LB agar plate (glass-pearls were used to obtain an even distribution), incubated $\left(25^{\circ} \mathrm{C}\right.$ for $72 \mathrm{~h}$ ) and counted. It has to be taken into account that MX80 has generally a larger grain size than nontronite and cells that are attached to the clay particles may have more difficulties to make contact with the agar plate, leading to a possible underestimation of the true number of CFU. To increase the reliability of measurements, preparations of each sample were repeated twice.

\subsubsection{Confined volume experiments}

In situ reaction-cell X-ray diffraction (XRD) was applied to monitor the influence of $S$. putrefaciens on compacted smectite under confined volume conditions. The reaction-cell device ("wet-cell" of Warr and Hofmann, 2003), a small reaction chamber made of a carbon Teflon compound, can be routinely mounted onto the X-ray diffractometer. It allows in situ measurement of hydration reactions during the infiltration of a solution into fine-grained smectite powders (Fig. 1). Because of the extensive swelling, the material self-seals and no solution or solids leave the reaction-cell. The sample is, perpendicular to the flow direction, about $4 \mathrm{~mm}$ thick, of which the XRD beam only penetrates the uppermost $\sim 1 \mathrm{~mm}$.

The average total sample packing density is $1.6 \mathrm{~g} / \mathrm{cm}^{3}$ (corresponding dry packing density of $\sim 1.3 \mathrm{~g} / \mathrm{cm}^{3}$ ) for MX80 and $1.34-$ $1.37 \mathrm{~g} / \mathrm{cm}^{3}$ for nontronite. This is lower than the dry packing density of the compressed bentonite blocks to be applied in repository sites $\left(>1.8 \mathrm{~g} / \mathrm{cm}^{3}\right)$ and more characteristic of interfacial environments (Stroes-Gascoyne et al., 2008). Therefore our experiments simulate rather local low-packing density interfacial environments and not the conditions in highly compacted blocks.

To conduct confined volume experiments, powdered, sterilized material of nontronite (between 4.6 and $4.8 \mathrm{~g}$ ) and MX80-bentonite $(\sim 5.6 \mathrm{~g})$ was added to $0.6-0.8 \mathrm{ml}$ of Millipore ${ }^{\odot}$ water containing
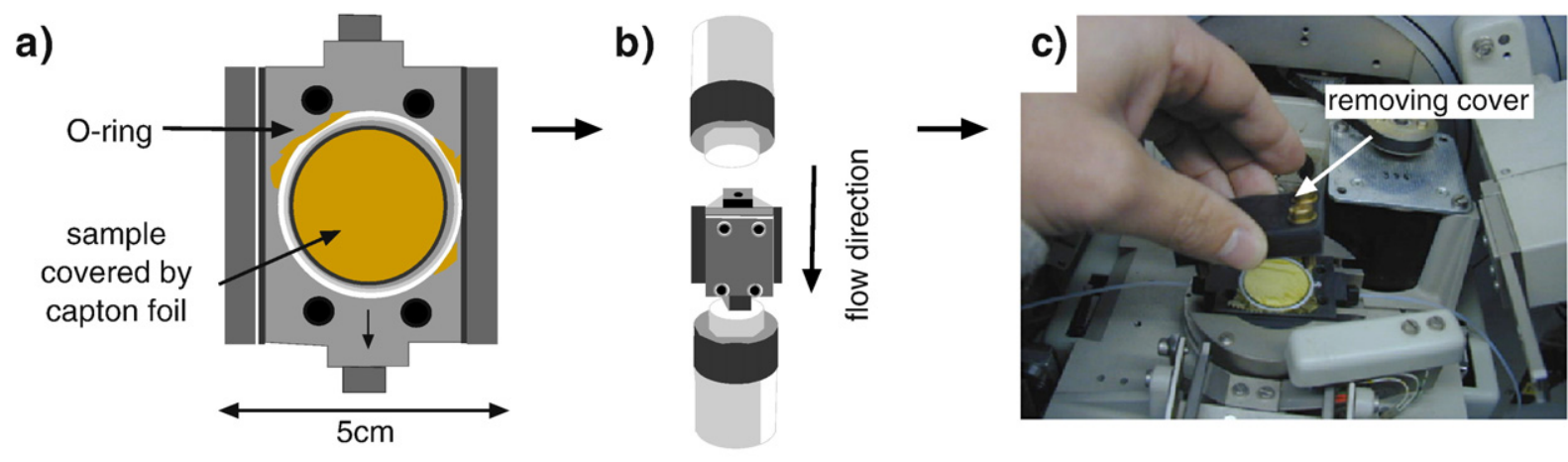

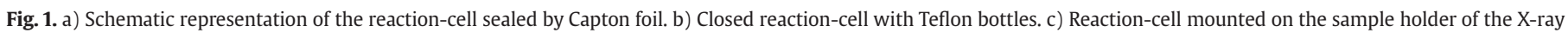
diffractometer. 
bacteria (density 1E08 CFU/ml) and mixed with a sterile spatula. Like for the batch experiments, the sterility of the samples was tested on LB agar plates. As the experiments were conducted under anaerobic conditions, the cultures were, prior to experimentation, adapted to metal Fe(III) respiration. For this purpose the stock culture was washed and grown in defined minimal medium (M1, Myers and Nealson (1988)) for $72 \mathrm{~h}$ at $25^{\circ} \mathrm{C}$. The culture was supplemented with $20 \mathrm{mM}$ formate, as an electron donor, and $80 \mathrm{mM} \mathrm{Fe}$ (III) citrate, as the TEA. The preparation was then stored anaerobically by using the GEN-bag anaerobic system provided by BioMerieux ${ }^{\odot}$, which consists of generators that react $\mathrm{O}_{2}$ to produce $\mathrm{CO}_{2}$. $\mathrm{Fe}$ (III)-adapted cultures were then washed and mixed with the smectite-based powder and loaded into the reaction-cell for in situ measurement. During the mixing with the smectite, anaerobic conditions were not maintained for $\sim 10 \mathrm{~min}$.

The reaction-cell was sealed by a thin X-ray transparent Capton ${ }^{\odot}$ foil and held in place with a sealing Teflon O-ring (Fig. 1a). Around $200 \mathrm{ml}$ of solution contained in a $8 \mathrm{~cm}$ tall Teflon bottle is directly screwed onto the cell to allow inflow (Fig. 1b). Inflow filters at the entrance of the cell $(<0.45 \mu \mathrm{m})$ prevent contaminations with unwanted microbes.

In order to maintain constant reaction volume during the experiment, a pressure cap was screwed to the top of the cell and only removed for XRD study (Fig. 1c). Depending on the measuring range, the time the pressure cap was removed ranged between 20 and $40 \mathrm{~min}$. This time span was short enough to avoid pressure release related expansion that would have affected the sample height and thus the XRD measurement. Water uptake was determined gravimetrically before and after measurements. Due to the presence of the Caption foil, evaporation of water could be minimized and did not affect the gravimetric measurements. Subsequent measurements were made at selected intervals throughout the experiment, enabling sequential XRD patterns to be plotted against time. The frequency of measurements was adjusted according to the observed rate of reaction. For bacteria-containing samples, the measurement frequency was kept low in order to minimize radiation damage and disturbance of the experimental setup. Because the experimental set up is not designed for routine sampling, only limited data are available on the long-term viability of bacteria. However, tests performed after $\sim 500 \mathrm{~h}$ ( 3 weeks) of experimentation confirmed the presence of viable cells in the order of $\sim 1 \mathrm{E} 04 \mathrm{CFU} / \mathrm{g}$ for both nontronite and MX80.

\subsubsection{Solid phase analysis}

2.2.3.1. X-ray diffraction. XRD is particularly adapted for the study of smectite as the thickness of the hydrated interlayer space can be resolved from the $d$-values of the 001 XRD peaks (Hofman and Bilke, 1936; Bradley et al., 1937; MacEwan and Wilson, 1980). This dimension varies depending on the amount of adsorbed water and the type of hydrated interlayer cations and therefore increasing interlayer hydration can be monitored. Analyses were made using a theta-theta Bruker Siemens D5000 diffractometer with CuKa radiation, operated under a potential of $40 \mathrm{kV}$ and a beam current of $30 \mathrm{~mA}$ with $1^{\circ}$ divergent aperture diaphragms and a $0.15^{\circ}$ detector diaphragm. Scanning parameters were set at 0.02 step width and a count time of $10 \mathrm{~s}$. The measurement range was selected to suite selected samples and ranged between 2 and $15-50^{\circ} 2 \theta$. Intensity variations between measurements caused by textural changes in the sample were calibrated by normalizing the height to the (001) kaolinite reflection at 7.14 $\AA$ in the case of nontronite (the kaolinite was added to the upper part of the sample during preparation). For MX80, the calibration was performed using the $4.26 \AA$ and $3.34 \AA$ quartz reflections.

2.2.3.2. Quantification of hydration using CALCMIX. The hydration structure of smectite interlayers was quantified by comparison with calculated patterns using the CALCMIX software provided by Plançon and Drits (1999). This software calculates the theoretical diffraction patterns of mixed-layer phases based on Mérings' principle (Méring, 1949). In order to calculate different mixtures of different water layer (WL) structures, the standard mineral data base was modified for smectites containing 0,1-, 2-, 3- and 4-WLs. The relevant chemical composition and structure of the minerals was entered in the minerals database of the program.

After selecting the WL structure, an appropriate mean defect free (particle) thickness was selected and fitted to the broadening peaks. The thickness distribution was calculated assuming lognormal distributions (Drits et al., 1997, 1998) and the degree of ordering for mixed-layered water-layer structures (the Reichweite) was selected manually.

The relative abundance of WLs obtained from CALCMIX calculations was used to estimate the amount of interlayer water based on data obtained from isotherm absorption experiments (Bérend et al., 1995; Cases et al., 1997). Those experiments were conducted in conditions of elevated air humidity ( $\mathrm{RH})$, as opposed to this study, where solutions are infiltrated. As more than 2 water layers were not observed in $\mathrm{RH}$, values for structures $>2 \mathrm{WL}$ were extrapolated from the isotherm curves (Warr and Berger, 2007). For the MX80 bentonite sample, the following values were used: $1-W L=0.09 \mathrm{ml} / \mathrm{g}, 2-\mathrm{WL}=0.18 \mathrm{ml} / \mathrm{g}$, $3-\mathrm{WL}=0.27 \mathrm{ml} / \mathrm{g}, 4-\mathrm{WL}=0.36 \mathrm{ml} / \mathrm{g}$.

The total water uptake into smectite samples during hydration was determined by monitoring gravimetrically the relative weight change of the reaction-cell apparatus throughout experimental runs. Subtraction of the calculated interlayer water from the measured total water content yields the volume of surface- and pore-water in the samples (i.e. non-interlayer water (Warr and Berger, 2007)). In order to increase the reliability of the measurements, the samples were treated following exactly the same procedure. The extent of evaporation during measurements was tested on separate experiments and was seen to be insignificant as long as the duration of measurement was under $2 \mathrm{~h}$.

2.2.3.3. Microscopy. Optical microscopy was used to investigate the formation of biofilm in smectite bacteria mixtures. Diluted bacteriacontaining and sterile smectite suspensions were directly pipetted onto a glass slide and studied in the wet state.

Transmission electron microscopy (TEM) was undertaken coupled with energy dispersive X-ray spectroscopy (EDX) using a Philips STEM 420 that is equipped with an Oxford INCA EDX system and a SIS Megaview II CCD camera. Samples were prepared by directly pipetting dilute suspensions onto carbon-coated formvar $\mathrm{Cu}$ TEM grids and letting them air-dry under a cover at room conditions. Microchemical information was obtained from distinct smectite particles and bacteria cells by coupled TEM and EDX without staining them. The acceleration voltage of $120 \mathrm{kV}$ was chosen as it incurs minimal damage to the bacterial cells in transmission mode (Perdrial et al., 2008). Because of the low resistance to irradiation of bacteria and smectites, the counting time for analyses was reduced to $30 \mathrm{~s}$ and analyses were done with the sample in the eucentric position at an angle of $+20^{\circ}$ to the detector. Microchemical analyses (C-N-O-Na-Mg-Al-Si-P-S-Cl-K-Ca-Mn$\mathrm{Fe}-\mathrm{Cu}-\mathrm{Zn}$ ) were carried out in transmission mode with the same acceleration voltage and with the fluo-X signals being recorded between 0 and $20 \mathrm{keV}$ with a $\mathrm{Si} / \mathrm{Li}$ detector and an atmospheric ultrathin window (ATW). Due to the composition of both the organic membrane and the carbon coating, a constant $C$ background is present in the EDX analyses and, therefore, the $\mathrm{C}$ detected in the particles cannot be interpreted quantitatively.

\section{Results}

\subsection{Batch experiments}

3.1.1. Bacterial growth in nontronite and MX80 bentonite suspensions

The growth curves for $S$. putrefaciens in the agitated, aerobic batch experiments are shown in Fig. 2. For comparison, experimental results 


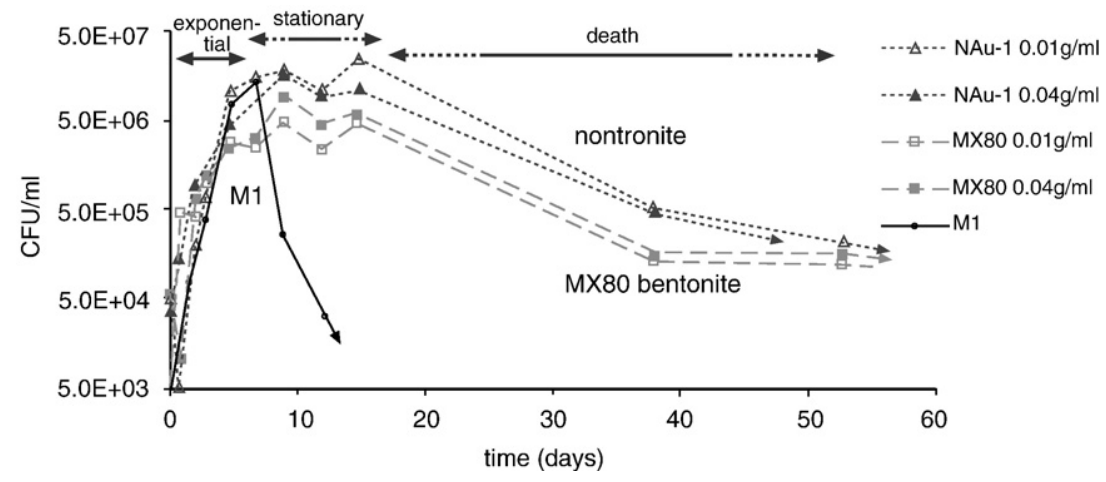

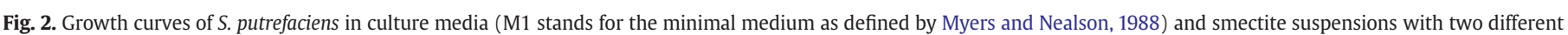
mineral concentrations, expressed in CFU/ml vs. time in days. Different growth phases (exponential growth phase, stationary phase and death phase) are indicated by arrows.

in water and the defined M1 medium (Myers and Nealson, 1988) were also obtained. As both these curves are almost identical, only the M1 is shown. The shape of all curves is typical of bacterial growth in a batch system with 3 visible, distinct phases characterizing the growth cycle (exponential, stationary and death phase). The exponential growth phase starts with sample-dependent slope gradients and CFU count maxima. Relatively steep slopes occur for all samples with the highest maximum for growth in nontronite $(2.5 \mathrm{E} 07 \mathrm{CFU} / \mathrm{ml}$ in $0.01 \mathrm{~g} / \mathrm{ml}$ and $1.68 \mathrm{E} 07 \mathrm{CFU} / \mathrm{ml}$ in $0.04 \mathrm{~g} / \mathrm{ml}$ ) and M1 (1.42E07 CFU/ $\mathrm{ml})$. In contrast, the maximal number of CFU in MX80 bentonite is lower at 9.0E06 CFU/ml and 5.0E06 CFU/ml for $0.01 \mathrm{~g} / \mathrm{ml}$ and $0.04 \mathrm{~g} / \mathrm{ml}$, respectively. The longest doubling time therefore characterises MX80, with up to $56 \mathrm{~h}$, whereas the doubling time in nontronite is shorter (e.g. $28 \mathrm{~h}$ when incubated in $0.04 \mathrm{~g} / \mathrm{ml}$ ). This indicates that during active growth, the nontronite suspensions are slightly more suitable to support bacterial growth than the MX80 bentonite suspensions.

The main difference between the smectite-based suspensions and the growth in M1 concerns the duration of the stationary and death phase, which is significantly longer for the smectite suspensions (Fig. 2). The length of the stationary phase observed within the M1 cannot be accurately determined but can be estimated to last for only 1 or 2 days, whereas the death phase is accomplished within 10 days. In contrast, the death phase duration in the smectite suspensions is much longer with at least 25 days for nontronite and for MX80 bentonite suspensions; compared to the M1, this is 25 times longer. After 60 days of experimentation the number of $\mathrm{CFU} / \mathrm{ml}$ leveled out.
As contaminations from airborne organisms occurred, the final stages of the death phase are not shown.

\subsubsection{Solution chemistry}

Fig. 3 shows the concentration of cations released to solution after 2 and $264 \mathrm{~h}$ of incubation time with S. putrefaciens for nontronite (left) and MX80 bentonite suspension (right). After a reaction time of $2 \mathrm{~h}$, the first ICP measurements of the nontronite suspension showed $\mathrm{Si}, \mathrm{Ca}$ and $\mathrm{Fe}_{\text {(tot) }}$ dissolved in solution and virtually no Al (light grey columns). After $264 \mathrm{~h}$, no Al was detected, whereas the concentration of Si was slightly enhanced. Ca remained constant and Fe showed a slight decrease.

In these experiments, all the analyzed cations in solution had a lower concentration than the abiotic control indicating bacterially induced depletions of all analyzed elements. The largest difference were seen after only $2 \mathrm{~h}$ of reaction with 12 times less $\mathrm{Al}(-7.8 \mathrm{mg} / \mathrm{l})$, 5 times less Si $(-38.8 \mathrm{mg} / \mathrm{l})$ and 12 times less Fe $(-44.4 \mathrm{mg} / \mathrm{l})$ compared to the abiotic control. Values for Ca were around 2 times lower after $2 \mathrm{~h}(-9.9 \mathrm{mg} / \mathrm{l})$ and around 2.5 times lower after $264 \mathrm{~h}$ $(-12.3 \mathrm{mg} / \mathrm{l})$. The concentration of $\mathrm{Al}$ and $\mathrm{Si}$ after $264 \mathrm{~h}$ of experimentation approached that of the sterile control whereas, in the case of Fe, the differences to the sterile experiment decreased but was still visible with 3 times less Fe in the bacteria-containing samples.

In contrast to the nontronite batch experiment, the cations released into the bacteria-containing MX80 bentonite suspension show roughly the same concentrations as the sterile control (Fig. 3). Interlayer cations $\mathrm{Na}$ and $\mathrm{Ca}$ are quickly released but, compared to the sterile

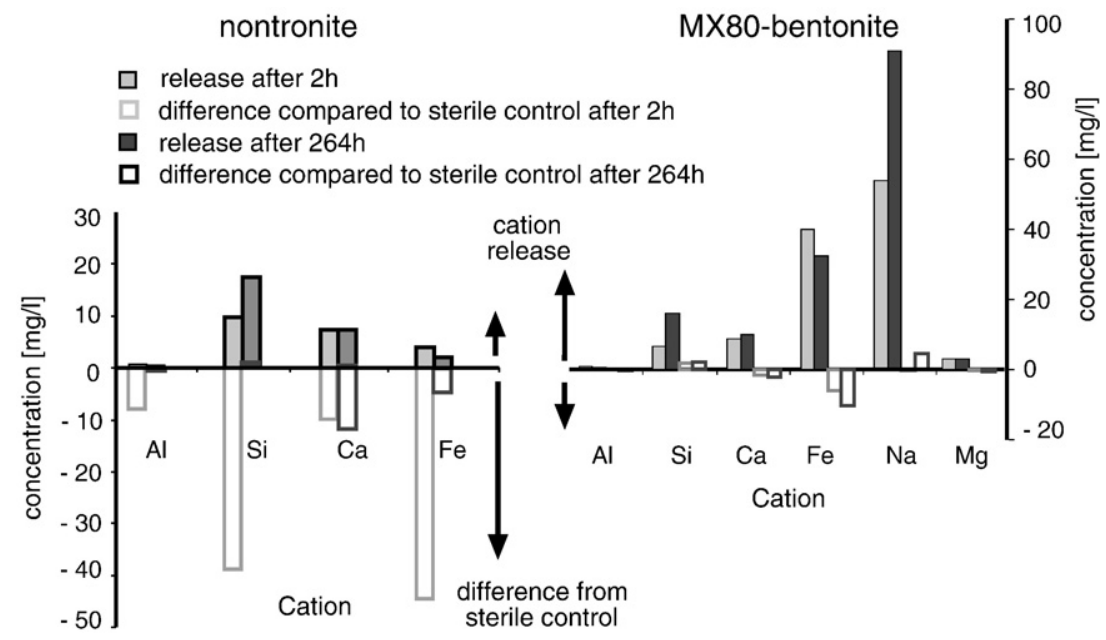

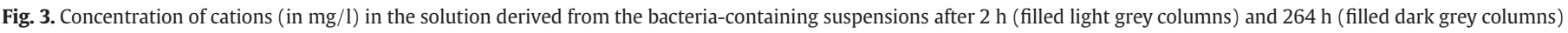

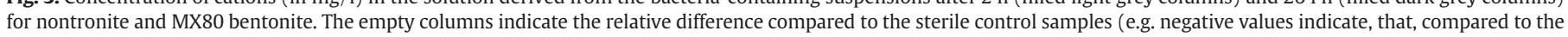
sterile control, less cations are detected in solution). 
control, not depleted. Fe, in contrast, is slightly depleted although oxidation of the $0.5 \%$ pyrite that occurs in the bulk material (Sauzeat et al., 2001) would be expected to increase the amount of Fe in solution. After $264 \mathrm{~h}$, the concentration of the interlayer cation Na is still relatively enhanced in solution, whereas lower concentrations of $\mathrm{Ca}$ and Fe in solution for MX80 reflect minor consumption or precipitation induced by the presence of bacteria. However, compared to the nontronite experiments, the bulk chemical alteration of MX80 bentonite due to the presence of $S$. putrefaciens appears to be relatively insignificant.

\subsubsection{Microscopic analysis}

Optical microscopy of the bacteria-containing nontronite and MX80 bentonite that were pipetted on glass slides after 1 week of incubation is shown in Fig. 4. The dark areas in the upper and lower left of Fig. 4a are montmorillonite aggregates, whereas single montmorillonite grains are visible in the center. Especially in the darker regions, diffuse structures could possibly be patches of biofilm as described in other studies (Aouad, 2006). Fig. 4b shows a microscope image of nontronite incubated with the bacteria under the same conditions. The grains of the nontronite are much smaller and the diffuse structure, characteristic of biofilm, is concentrated around smectite aggregates (indicated by a dotted line). This indicates biofilm induced aggregate formation, which could have important implications for the microstructure of the smectite and smectite-based materials.

TEM coupled to EDX investigations on the sterile and bacteriacontaining MX80 bentonite showed no significant modification of the clay, whereas the results on nontronite confirm bacterially induced chemical alteration. Fig. 5 shows microphotographs of sterile and bacteria-containing nontronite after 10 days of incubation. The sterile
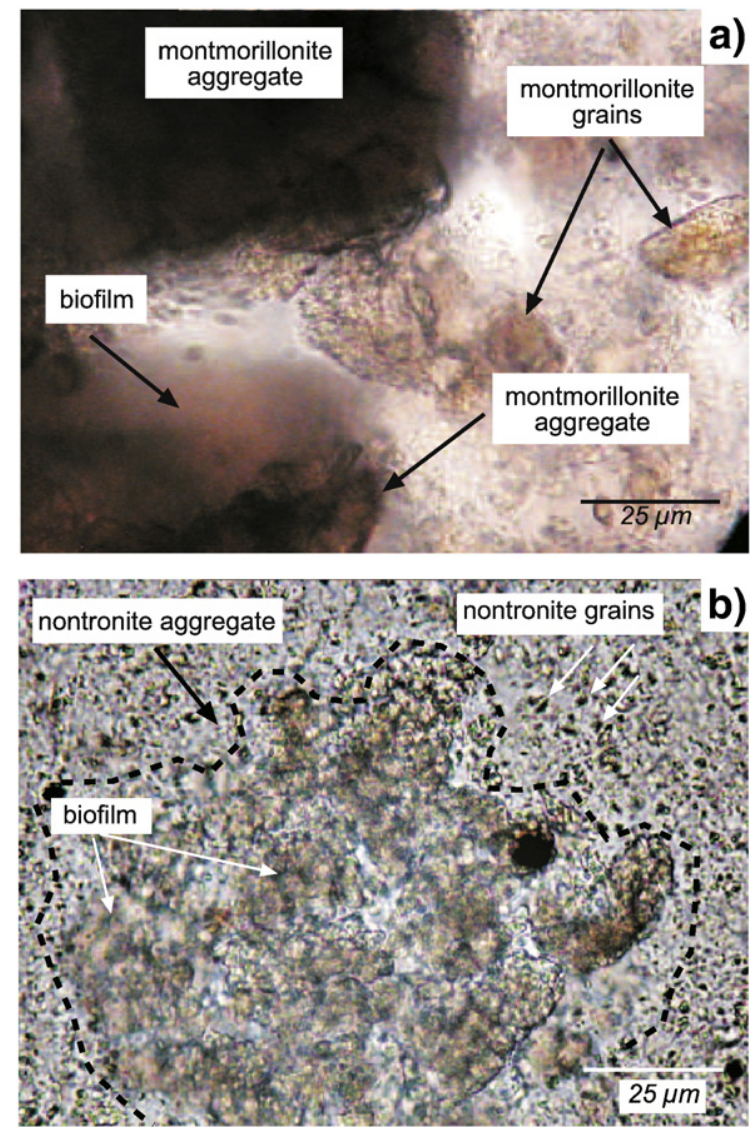

Fig. 4. Optical microscopy image of MX80 bentonite (a) and nontronite (b) incubated with $S$. putrefaciens for 1 week. Biofilm appears associated with smectite aggregates forming a diffuse structure the limits of which are indicated by the black dotted line in panel b. nontronite (Fig. 5a) is present as an aggregate, formed by small individual particles between 0.1 and $0.5 \mu \mathrm{m}$ in size. Microchemical semiquantification of the particle (Fig. 5b) shows the typically high values of $\mathrm{Fe}\left(12.1 \mathrm{wt} . \% \mathrm{Fe}_{\text {tot }}\right.$ ), low values of $\mathrm{Al}$ (3.27 wt.\% $\mathrm{Al}_{2} \mathrm{O}_{3}$ ) and the presence of $\mathrm{Ca}$ as the exchangeable cation ( $1.9 \mathrm{wt} . \% \mathrm{CaO})$. The bacteriacontaining nontronite sample (Fig. 5c) shows particles with diffusely defined edges surrounded by a homogenous substance. Dark field imaging confirmed the amorphous character of this substance. Corresponding microchemical analysis of the electronically denser regions (Fig. 5d), show high values of $\mathrm{Fe}\left(10.2 \mathrm{wt} . \% \mathrm{Fe}_{\text {tot }}\right)$ and low concentrations of $\mathrm{Al}\left(2.8 \mathrm{wt} . \% \mathrm{Al}_{2} \mathrm{O}_{3}\right)$ and small amounts of $\mathrm{Ca}(1.3 \mathrm{wt} . \%$ $\mathrm{CaO})$, whereas the analyse performed on the amorphous material (Fig. 5e) shows only traces of Fe and $\mathrm{Ca}\left(0.5 \mathrm{wt} . \% \mathrm{Fe}_{\text {tot }}\right.$ and $0.6 \mathrm{wt} . \% \mathrm{CaO}$, not indicated in spectra), no $\mathrm{Al}$, and is almost entirely composed of $\mathrm{Si}$ ( $46.3 \mathrm{wt} . \% \mathrm{SiO}_{2}$ ). Note that the values for semi-quantification are not corrected for the $\mathrm{C}$ contribution from the grid substrate.

\subsection{Confined volume environments}

\subsubsection{Total water uptake}

One important measure of smectites capacity to hydrate is the amount of water that can be taken into the closed system. Fig. 6 shows the total water uptake into the nontronite and MX80 bentonite powder with and without $S$. putrefaciens plotted against time. The compacted, sterile nontronite powder (packing density $1.34 \mathrm{~g} / \mathrm{cm}^{3}$ ) shows a high rate of water uptake and reaches a stable state after only $\sim 72 \mathrm{~h}$ with a total of $0.17 \mathrm{ml} / \mathrm{g}$ (Fig. 6a). The equivalent bacteria-containing nontronite powder (packing density $1.37 \mathrm{~g} / \mathrm{cm}^{3}$, inoculated with 2.8E06 CFU per g smectite) shows a slightly higher and slower water intake, reaching the steady state of $0.19 \mathrm{ml} / \mathrm{g}$ after $\sim 840 \mathrm{~h}$. The uptake rates are accordingly higher for the sterile sample $(2.4 \mathrm{E}-03 \mathrm{ml} / \mathrm{g} / \mathrm{h})$ compared to $2.3 \mathrm{E}-04 \mathrm{ml} / \mathrm{g} / \mathrm{h}$ for the bacteria-containing sample. Generally, however, the differences between sterile and bacteriacontaining samples are relatively moderate.

In contrast, for the MX80 bentonite powders (packing density $1.6 \mathrm{~g} / \mathrm{cm}^{3}$ ), the difference between sterile and bacteria-containing sample is apparent (Fig. 6b). The sterile powder shows, with a total intake of $0.10 \mathrm{ml} / \mathrm{g}$, less solution intake (stable state after $1990 \mathrm{~h}$ ) than the bacteria-containing powder (initial bacterial density 5.7E04 CFU per g smectite), which takes in $0.16 \mathrm{ml} / \mathrm{g}$ (around 37\% more water uptake) during $\sim 3100 \mathrm{~h}$. Water inflow rates are however similar, with $5.0 \mathrm{E}-05 \mathrm{ml} / \mathrm{g} / \mathrm{h}$ and $5.2 \mathrm{E}-05 \mathrm{ml} / \mathrm{g} / \mathrm{h}$ for the sterile and bacteria-containing MX80 bentonite, respectively.

\subsubsection{Interlayer water}

The total amount of water taken into the powders can be either stored in the smectite interlayers, leading to additional swelling and sealing, or it can be present as external water (as surface- and porewater) indicating a decreased sealing capacity. Diffraction peak calculations (performed with CALCMIX) were applied to obtain the interlayer water distributions in the MX80 bentonite smectite in order to observe the interlayer hydration state of both powders, without and with S. putrefaciens (Fig. 7a+b). For the sterile sample (Fig. 7a), the initial state comprises 45\% 3-WL, 15\% 2-WL and 40\% 1-WL. The 1-WL structure decreases continuously until disappearing completely after $1038 \mathrm{~h}$, when the 4-WL structure (10\%) develops. The 2 -WL remains stable as long as the 1-WL is present and, subsequently decreases until stabilizing at $10 \%$ after $1038 \mathrm{~h}$. The 3 -WL continuously increases from the beginning of hydration and stabilizes after $1998 \mathrm{~h}$ as the most abundant structure (80\%). The highest rates of total water uptake (curve normalized to 100\%) correspond to the initial increase in 2-WL during the first hours of hydration and the more persistent increase in 3-WL occurring up to $1500 \mathrm{~h}$.

When bacteria are present, the 1 and 2-WL (each with an initial abundance of $30 \%$, Fig. $7 \mathrm{~b}$ ) decrease more rapidly than observed in the sterile sample and both structures are replaced by thicker hydrated 

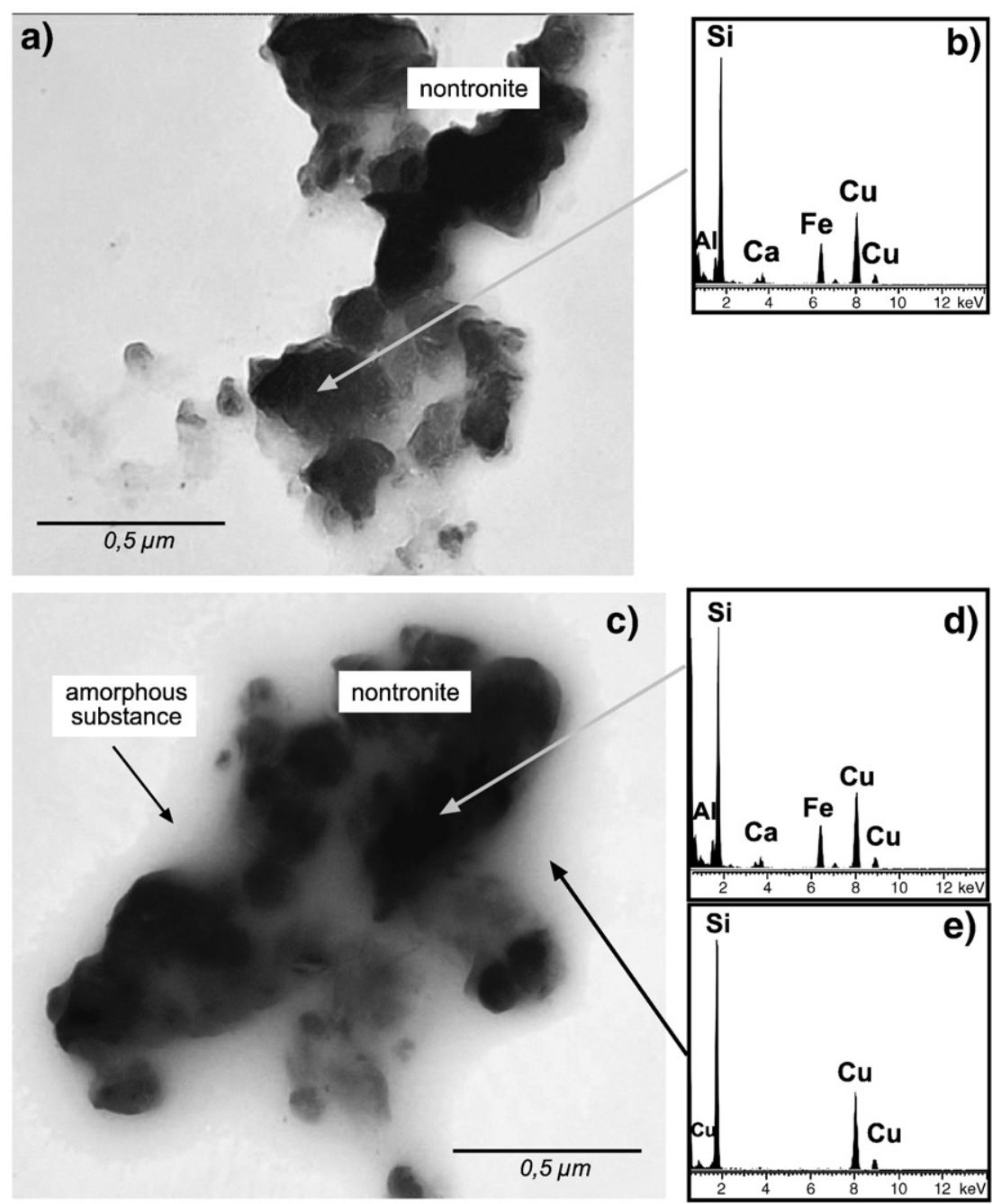

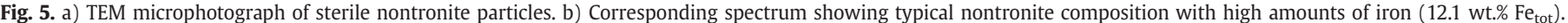

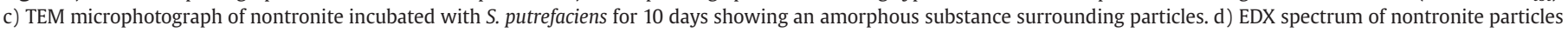

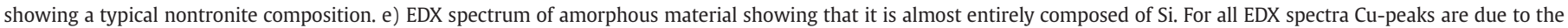
sample grid.

structures. Here, the 1-WL decreases to 17\% and its disappearance matches with the formation of 4-WL (starting with 18\%) after $630 \mathrm{~h}$. In the case of the 2-WL, it decreases down to $5 \%$ and disappears after $1279 \mathrm{~h}$. This corresponds with the formation of a structure at $\sim 22.4 \AA$ (for reasons of simplicity referred to as 5 -WL structure) that remains constant at $5 \%$. As seen for the sterile sample, the $3-\mathrm{WL}$ structure dominates but develops more quickly in the presence of bacteria. In the case of the inoculated samples, the stable state is reached in a third of the time required for the sterile samples, after only $\sim 630 \mathrm{~h}$, and stabilizes with 68\% 3-WL, 27\% 4-WL and 5\% 5-WL structures. Total water intake also continues after stabilization of the interlayer structure (after $2500 \mathrm{~h}$ ), showing a similar behaviour to the abiotic (sterile) sample.

Overall the results indicate thicker water structures are formed in montmorillonite when bacteria are present. Expressing the WL distributions as mean thicknesses (d-values), yields $15.6 \AA$ for the sterile sample at initial and $18.3 \AA$ at final stages of the experiment and therefore the mean increase of water-layer thickness is $2.7 \AA$ A. In contrast
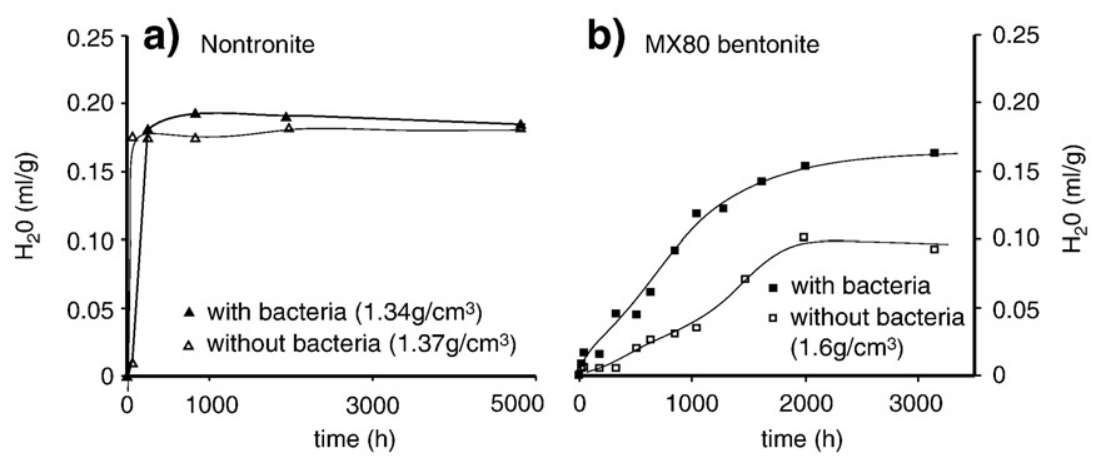

Fig. 6. Total water uptake (in $\mathrm{ml} / \mathrm{g} \mathrm{H}_{2} \mathrm{O}$ vs. time) into sterile and bacteria-containing nontronite (a) and MX80 bentonite (b) powders as determined by weight gain. 

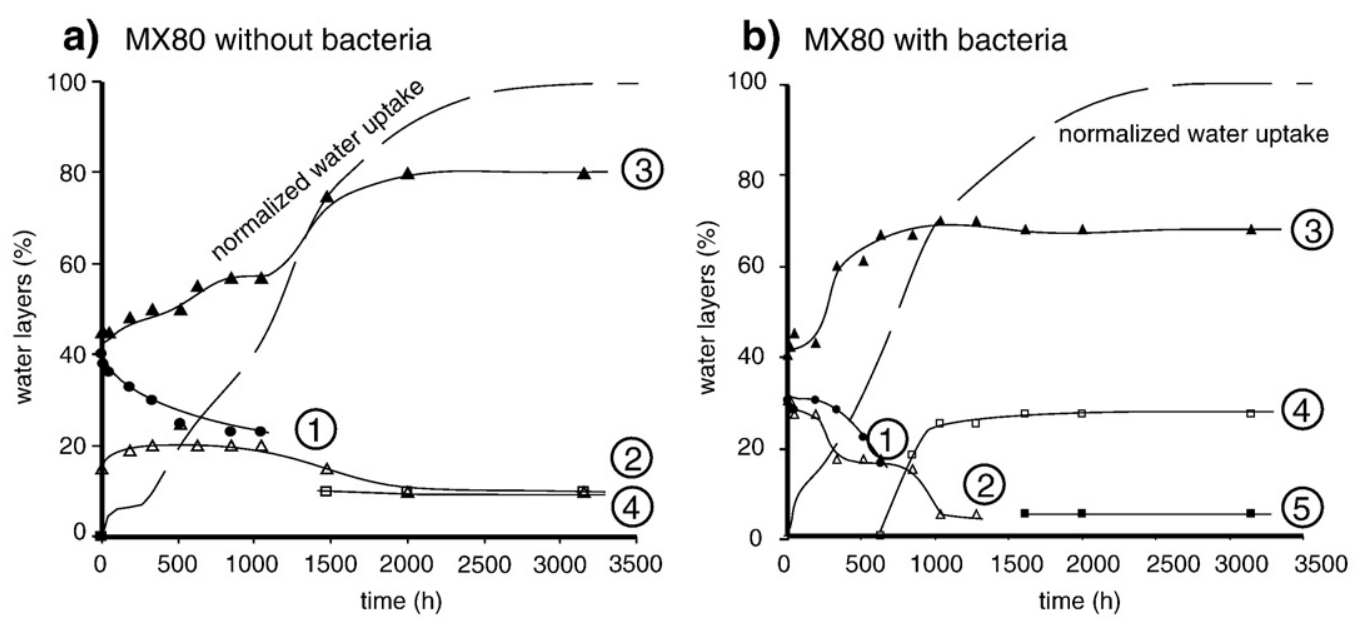

\section{C) $\mathrm{MX80}$ without bacteria}

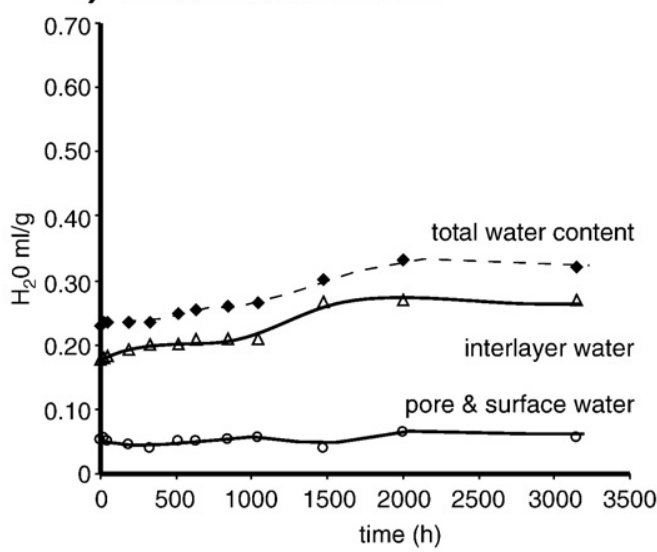

d) MX80 with bacteria

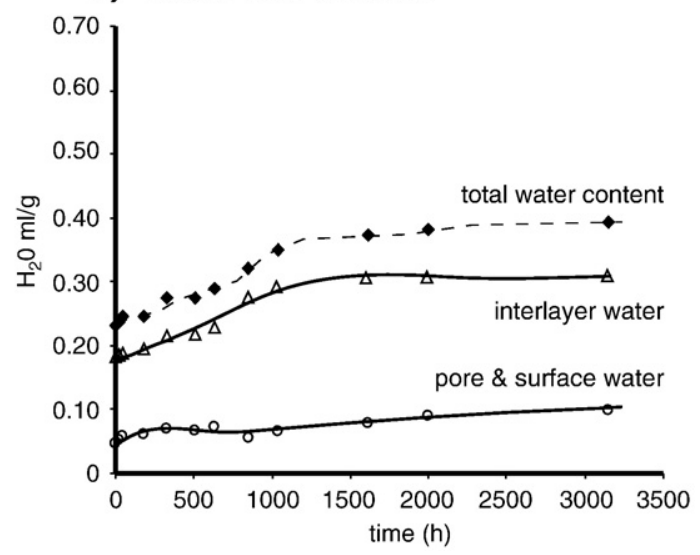

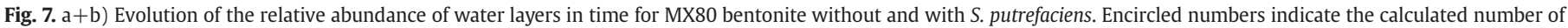

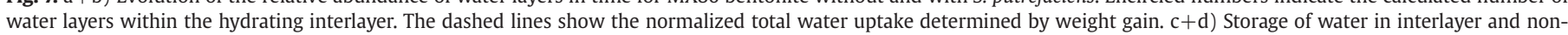
interlayer sites (in $\mathrm{ml} / \mathrm{g} \mathrm{H}_{2} \mathrm{O}$ per hours) of the montmorillonite contained in the MX80 bentonite without and with S. putrefaciens.

the mean increase of water-layer thickness in the bacteria-containing sample yields $3.5 \AA$ ( $15.7 \AA$ at initial stages and $19.2 \AA$ at final stages) indicating a significant increase in sealing interlayer water.

\subsubsection{Water-storage}

The total amount of interlayer water was quantified based on published water vapour absorption data (Cases et al., 1992; Bérend et al., 1995; Cases et al., 1997) and subtracted from the measured total water uptake to obtain the amount of external water (Warr and Berger, 2007). Corresponding curves are displayed for sterile (Fig. 7c) and bacteria-containing (Fig. 7d) MX80 bentonite. As significant amounts of solution were introduced during the mixing process of smectite and bacteria (each containing $0.23 \mathrm{ml}$ solution with or without bacteria per $g$ smectite) the initial water is included.

Because the samples were treated exactly in the same way (including preparation time), the initial proportions of total, interlayer and external (surface and pore) water prior to water inflow are the same. The initial total water content $(0.23 \mathrm{ml} / \mathrm{g})$ is distributed as $82.6 \%$ in the interlayers $(0.19 \mathrm{ml} / \mathrm{g})$ and to $17.4 \%$ in external sites $(0.05 \mathrm{~g} / \mathrm{ml})$. A significant difference in the total water content between the sterile and bacteria samples is observable after hydration is complete, with a higher amount of water incorporated in the presence of bacteria $(0.39 \mathrm{ml} / \mathrm{g}$ as opposed to $0.32 \mathrm{ml} / \mathrm{g})$. This additional water $(0.07 \mathrm{ml} / \mathrm{g})$ in the bacteriacontaining sample is almost equally distributed between interlayer and external sites $(0.03 \mathrm{ml} / \mathrm{g}$ and $0.04 \mathrm{ml} / \mathrm{g}$, respectively).

These observations indicate that the presence of bacteria in MX80 bentonite leads to a general and persistent enhancement of water content in both interlayer and external storage sites.

\subsubsection{Whole rock analysis}

The MX80 bentonite contains, besides 76\% montmorillonite, accessory minerals, in particular calcite and pyrite (Sauzeat et al., 2001) that are very sensitive to changes in $\mathrm{pH}$ and redox conditions (Table 1). In order to study the behaviour of those accessory minerals, the XRD measurement range was extended to ${ }^{\circ} 502 \theta$ at selected measurement points. Fig. 8a shows the different whole rock XRD patterns of the sterile MX80 bentonite during a time span of $3150 \mathrm{~h}$ and Fig. $8 \mathrm{~b}$ shows the corresponding results of the $S$. putrefaciens containing MX80 bentonite powder.

Dominant reflections are montmorillonite (reflections are indicated for 2 and 3 water layers), an illite-type mica ( $9.95 \AA$, $4.47 \AA$ and $2.56 \AA$ ), quartz (4.26 $\AA$ and $3.34 \AA$ ) and feldspar (mostly albite with multiple reflections). A clear sequence of crystallization is visible for an iron carbonate hydroxide $\left(\mathrm{Fe}_{6}(\mathrm{OH})_{12}\left(\mathrm{CO}_{3}\right)\right)$ referred to as "green rust" which is identifiable by the strongest reflection at $7.58 \AA$. This reflection is not present at initial (almost dry) states and occurs with fluctuating intensities throughout experimentation, both in the sterile MX80 bentonite (Fig. 8a) and bacteria-containing material (Fig. 8b), indicating active Fe dissolution and precipitation reactions. The reaction product has also been described in other studies (Sauzeat et al., 2001) and is most easily detected under hydrated conditions. Other non-silicate reflections are present in some measurements but are not present in all patterns, such as the calcite $\left(\mathrm{CaCO}_{3}\right.$, visible reflection at $3.88 \AA$ and $2.29 \AA)$, rhodochrosite $\left(\mathrm{MnCO}_{3}\right.$, visible reflection at $2.17 \AA$ ) and bassanite $\left(\mathrm{CaSO}_{4} * 0.5 \mathrm{H}_{2} \mathrm{O}\right.$, visible reflection at 2.99 and $3.48 \AA$ ).

Reflections which are only recognizable in the bacteria-containing sample belong to lepidocrocite $((\gamma-\mathrm{FeOOH})$ visible at $2.46 \AA)$ that shows 

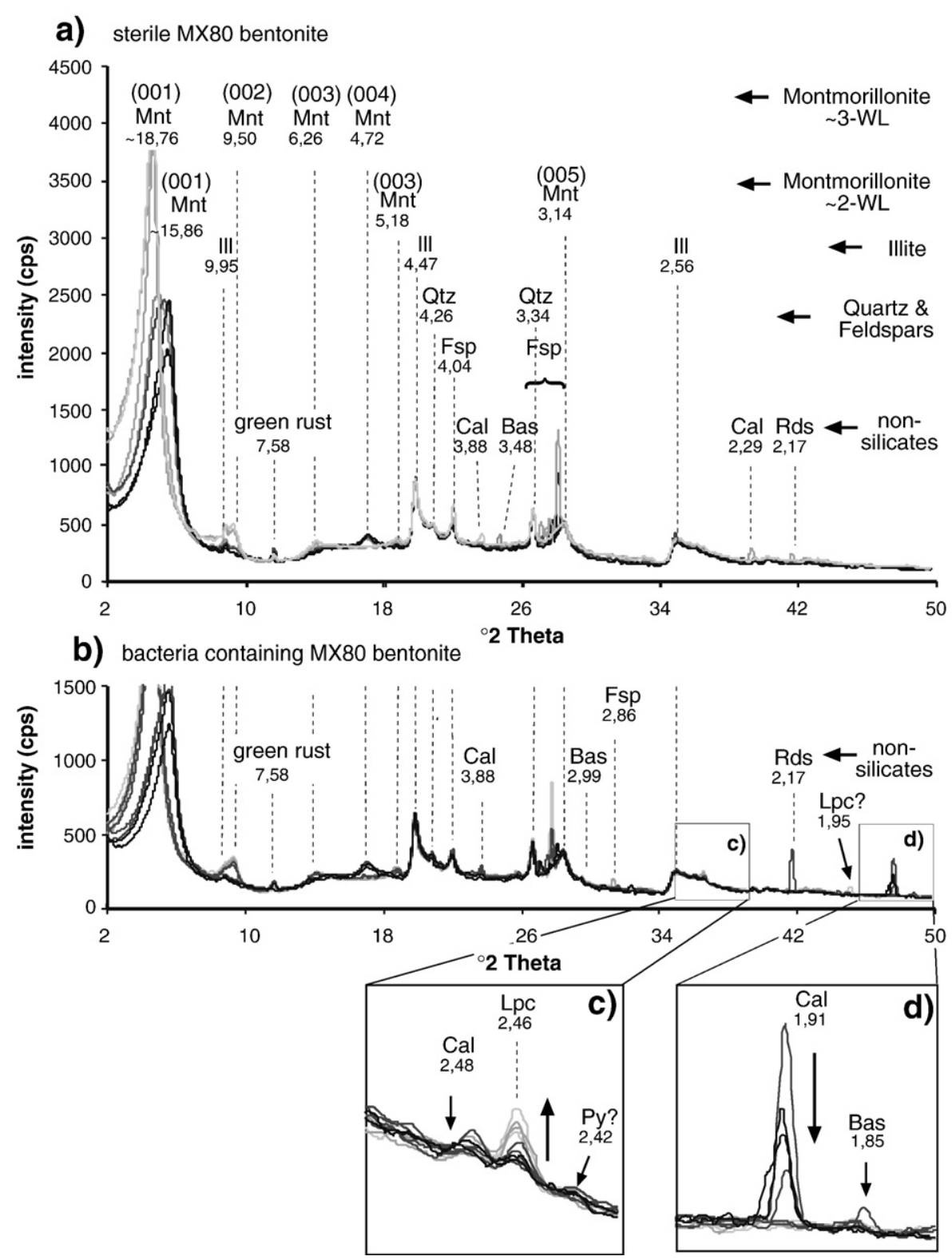

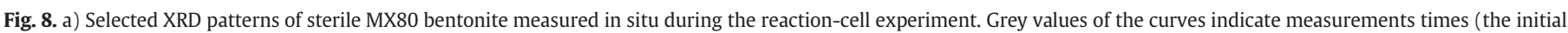

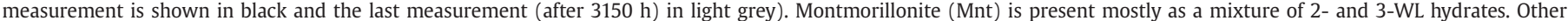

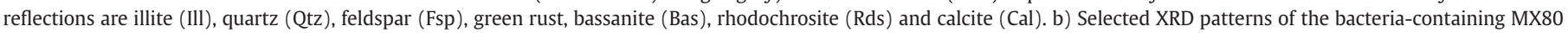
bentonite. c) Systematic increase of lepidocrocite (Lpc). d) Decrease of calcite (Cal). All $d$-values are given in $\AA$.

a progressive increase in XRD peak intensity indicating continuous precipitation (Fig. 8c). Another sequence, that is as well limited to the bacteria-containing sample, is the successive decrease of the calcite 2.48 A reflection intensity. This is even more notable for the reflection at $1.91 \AA$, showing the highest intensity at the beginning of the experiment, a successive decrease in peak intensity with time, and the complete disappearance by $190 \mathrm{~h}$ of experimentation (Fig. 8d).

\section{Discussion}

\subsection{Influence of clay and clay based materials on the growth of} S. putrefaciens

Based on the batch experiments conducted it is seen that $S$. putrefaciens grows better in nontronite clay than the MX80 bentonite: a difference which can be attributed largely to the mineral composition. One explanation for this observation is that the main exchangeable interlayer cation of nontronite is $\mathrm{Ca}$, which can act as an ionic bridge between the negatively charged clay particles and the likewise negatively charged bacteria. Divalent cations are known to facilitate bacterial adhesion and improve access to nutrients at the mineral surface, as reported from experiments conducted by Simoni et al. (2000). In contrast, the montmorillonite of the MX80 bentonite contains more $\mathrm{Na}(\sim 64 \%$ more $\mathrm{Na}$ than $\mathrm{Ca})$ in the interlayers and the degree of divalent bridging is reduced. Additionally, the restricted access of bacteria to mineral particles is likely to result from the extensive osmotic swelling that characterizes Na-montmorilloniterich suspensions. Here, the monovalent $\mathrm{Na}$ becomes increasingly hydrated and surrounded by a diffuse double layer, leading to the eventual formation of a gel (Hofman and Bilke, 1936; MacEwan and Wilson, 1980; Lagaly, 1993), which can significantly inhibit the free movement and survival of bacteria.

Another important compositional difference between MX80 bentonite and nontronite, which may explain the difference in S. putrefaciens activity is, that the latter clay contains significant amounts of $\mathrm{Fe}(\mathrm{III})$. This elemental species constitutes a key compound of many bacterial 
proteins especially of cytochromes and thus plays a major role in the energetic metabolism of the cell (Saier,1987). Therefore materials with high $\mathrm{Fe}$ (III) contents are likely to promote aerobic bacterial growth as seen by the enhanced growth of $S$. putrefaciens in the nontronite suspension.

Another factor required for sustained bacterial activity is the availability of organic carbon $\left(\mathrm{C}_{\mathrm{org}}\right)$. Neither nontronite nor MX80 bentonite were amended with an additional source of $C_{\text {org }}$ and both materials contain only small initial quantities. However, S. putrefaciens is heterotroph and does require a source of pre-existing organic material. MX80 bentonite contains $\sim 0.19 \%$ of $\mathrm{C}_{\text {org }}$ (Sauzeat et al., 2001) that provides a carbon concentration of 0.02 and $0.08 \mathrm{~g} / \mathrm{l}$ for a suspension density of 0.01 and $0.04 \mathrm{~g} / \mathrm{ml}$, respectively. Those values lie between the values of carbon-rich culture media $(>2 \mathrm{~g} / \mathrm{l})$ and the carbon-poor sediments typical of natural environments (0.001-0.015 g/l, Roszak and Colwell (1987)). The nontronite $C_{\text {org }}$ content was not determined but is expected to be significantly lower than the MX80 sample because the material was purified by washing several times during the grain size separation procedure.

The prolonged bacterial activity in materials with low concentrations of pre-existing $C_{\text {org }}$ indicates that starved cells release their carbon to aid the growth of new or surviving cells (Dean and Hinshelwood, 1966; Postgate, 1976). Electron microscopy revealed that the living cells are significantly smaller ( 0.5-1 $\mu \mathrm{m}$ length) than those initially introduced from the inoculum culture $(\sim 3-5 \mu \mathrm{m}$ length) and, therefore should require less energy and $C_{\text {org }}$ per unit cell. Such partial carbon recycling in the system is suggested to compensate for the initial low $C_{\text {org }}$ content. As only small amounts of $C_{\text {org }}$ will be present in engineered smectite-based barrier systems, bacterial survival mechanisms in a starvation situation should to be taken into account when evaluating the probability of their occurrence. The fact that bacteria are able to survive on such C-poor materials for significant periods of time indicates that, once the bacterial population is present, $\mathrm{C}_{\text {org }}$ should not be limiting factor for bacterial survival in the backfill barrier environment.

In addition to mineral composition other physicochemical properties of the clay can be expected to be of importance for the survival of S. putrefaciens. Being very fine-grained, the surface area (per g) of both clay materials is very high and is expected to adsorb toxic waste products during the death phase that would otherwise accelerate bacterial death. However, as MX80 bentonite has a specific surface area that is almost 3 times lower than the nontronite sample but no difference is observed in the duration of its death phase, the precise role of detoxification by adsorption on available minerals surfaces remains unclear.

\subsection{Stability of clay and clay based materials in the presence of bacteria}

\subsubsection{Influence of S. putrefaciens in solution dominated systems}

In aerobic batch experiments, the MX80 bentonite showed no sign of chemical alteration whereas the nontronite underwent significant dissolution by mechanisms specific to this Fe-smectite material. It is probable that specific organic ligands, siderophores, are produced to sequester iron, that otherwise would precipitate as insoluble oxides. Such ligands are likely to play an active role in the partial (nonreductive) nontronite dissolution as they are known to trigger overall mineral dissolution (Banfield and Hamers, 1997; Barker et al., 1997; Kostka et al., 1999; Banfield and Welch, 2000).

Our solution chemistry results reveal higher amounts of Si relative to $\mathrm{Al}$, which is in accordance with the preferred dissolution of nontronite tetrahedral edge sites (Bosbach et al., 2000; Bickmore et al., 2001). However, the release of Fe indicates additional dissolution of the octahedral sites. The relative depletion of cations in the extracted solution of the $S$. putrefaciens-nontronite mixture may relate to two mechanisms. Firstly, consumption of those cations by bacteria by complexation and binding as described by Beveridge (1989). This mechanism is most likely to occur in the case of Fe and Ca during the initial phases of growth, when such nutrients are required most. Secondly, a temporal storage of cations within biofilm or as secondary phase precipitations.

Extracellular storage is more likely to occur with $\mathrm{Al}$, as this element is toxic to most bacteria. Another possibility is that aluminum ions are combined with functional groups on the bacterial surface as noted by Fein et al. (2002) for Bacillus subtilis. This process was as well described to facilitate the adsorption of silicic acid and the precipitation of amorphous silica (Yokoyama et al., 2004) or amorphous clay like phases (Konhauser and Urrutia, 1999). The structure and composition indicates that the amorphous substance described in this study is related to partial dissolution of the nontronite as described in various studies (O'Reilly et al., 2006; Furukawa and O'Reilly, 2007). However, although EPS was described to be associated with such partly dissolved grains (Jaisi et al., 2007), its presence in our EDX analyzes could not be confirmed due to the lack of $\mathrm{P}$ and $\mathrm{S}$.

The less pronounced difference in cation concentrations between sterile and bacteria-containing suspensions observed after $264 \mathrm{~h}$ (11 days) appears to be related to the end of the exponential growth phase characterized by a decreasing growth rate and death of bacterial cells. As the experimental system is a closed one, this change can be related to the re-release of bacterially consumed cations into solution during cell breakdown (lyses).

In Fig. 9, a schematic representation illustrates a conceptual view of the overall effect that $S$. putrefaciens has on nontronite in solution. At unstable edge sites, $\mathrm{Fe}$ (III) is mobilized and most likely trapped by organic ligands that keep the iron in solution (Fig. 9a). At the same time $\mathrm{Ca}$ is released from the interlayer sites and serves as bridges between the bacteria and the smectite, thus facilitating access to the nontronite surface (Fig. 9b). The complexed Fe is transported to the cell membrane and then either transported into the cell, or forms coatings on the bacteria's surface. Accordingly, the increasing dissolution of the nontronite leads to enduring Si-release and the precipitation of the amorphous gel.

The fact that tetrahedrally coordinated $\mathrm{Al}$ is also depleted from nontronite during the initial stages of the batch solution experiments, but re-enters the solution (see Fig. 3a), indicates that $\mathrm{Al}$ might form additional bridges between bacterial cells and $\mathrm{Si}$, as reported for $B$. subtilis by Fein et al. (2002). This confirms that the metals are mostly associated with active cells but released when the cells die.

\subsubsection{Influence of S. putrefaciens in mineral dominated systems}

Under anaerobic, confined volume and mineral dominated conditions, other mechanisms are active compared to the solution dominated, aerobic, batch reactor system. In the reaction-cell, no significant difference was observed between the water uptake of the sterile and bacteria-containing nontronite, indicating that that bacteria activity is inhibited in this environment. Whereas cations most likely still serve as nutrients, the beneficial effect of Ca to aid cell attachment appears less important, as does the ligand aided solubilisation of $\mathrm{Fe}(\mathrm{III})$. These reactions are most likely inhibited by the lower effective clay mineral surface area and the reduced mobility of bacteria within the compacted, confined volume conditions (Table 2).

The experimental study of S. putrefaciens and compacted MX80 bentonite does show significant effects on both the montmorillonite and the accessory minerals. During hydration the degree of montmorillonite interlayer expansion is maintained when bacteria are present, which indicates an intact sealing capacity. This is accompanied by the general enhancement of the total water content, including non-interlayer water adsorbed on clay surfaces and stored within open pore spaces. As the initial packing densities were the same at the beginning of the sterile and bacteriacontaining experiments, the additional space that is required to accommodate the water can be attributed to bacterially induced textural changes. Such changes most likely involve the formation of aggregates during the interaction of organic matter and smectite 


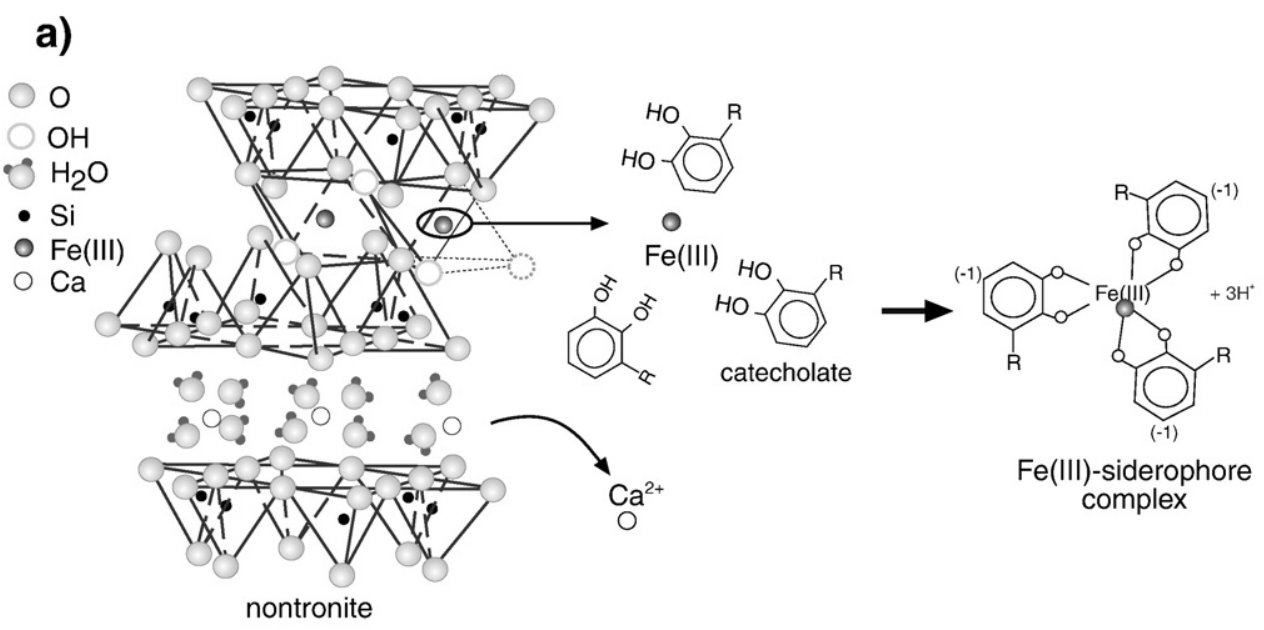

b)

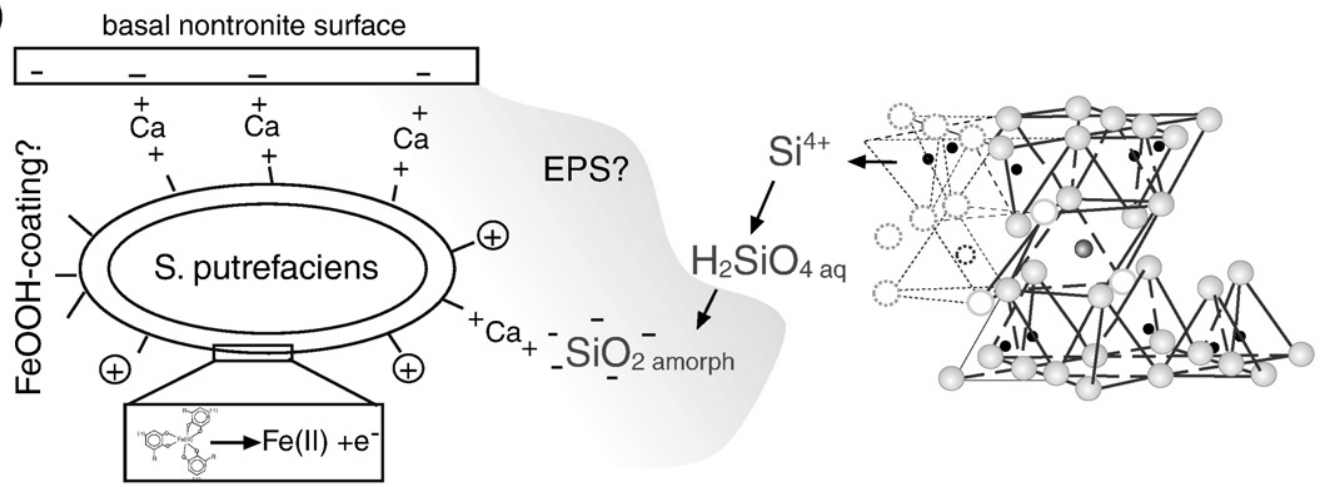

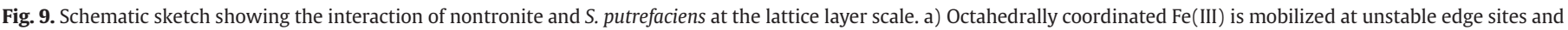

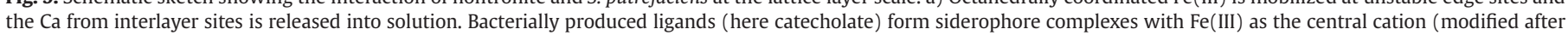

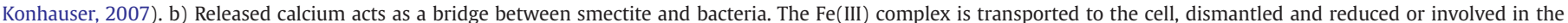

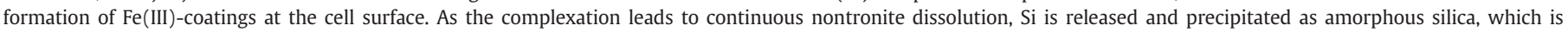
presumably associated with EPS.

(Jaisi et al., 2007) and also the dissolution and precipitation of accessory phases related to bacterially induced changes in Eh and $\mathrm{pH}$ conditions.

In both the sterile and S. putrefaciens containing confined volume MX80 bentonite experiments, the presence of "green rust" was detected. The Fe needed for its formation is most likely derived from pyrite oxidation occurring at initial stages in contact with the experimental solution according to the (simplified) reaction (Nordstrom, 1982):

$\mathrm{FeS}_{2}+15 / 2 \mathrm{O}_{2}+7 / 2 \mathrm{H}_{2} \mathrm{O} \rightarrow \mathrm{Fe}(\mathrm{OH})_{3}+2 \mathrm{SO}_{4}^{2-}+4 \mathrm{H}^{+}$

This reaction leads, besides a decrease in $\mathrm{pH}$, to the formation of sulphate and the precipitation of Fe(III)-hydroxides, which are then available to form the iron carbonate. The carbonate required for this formation may derive from the dissolved calcite according to the reaction (Morse, 1983):

$\mathrm{CaCO}_{3}+\mathrm{H}_{2} \mathrm{O} \rightarrow \mathrm{Ca}^{2+}+\mathrm{HCO}_{3}^{-}+\mathrm{OH}^{-}$

This reaction buffers the $\mathrm{pH}$ to some degree and leads to the release of Ca cations. The available calcium can then participate, together with sulphate (released from pyrite oxidation), to form bassanite, which is frequently found both in bacteria-containing and bacteria-free samples (Akpokodje, 1984):

$\mathrm{Ca}^{2+}+0.5 \mathrm{H}_{2} \mathrm{O}+\mathrm{SO}_{4}^{2-} \rightarrow \mathrm{CaSO}_{4} * 0.5 \mathrm{H}_{2} \mathrm{O}$

Dissolution and precipitation reactions are as well visible for bassanite and rhodochrosite $\left(\mathrm{MnCO}_{3}\right)$. As rhodochrosite formation requires iron reduction in combination with excess $\mathrm{HCO}_{3}^{-}$, its presence

Table 2

Summary of the mutual effects of nontronite and S. putrefaciens in solution and mineral dominated systems.

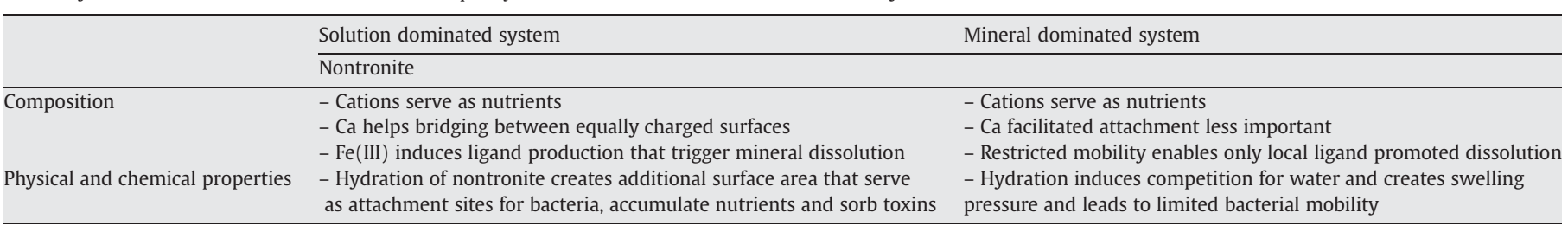


and disappearance indicates clear fluctuations in both Eh and $\mathrm{pH}$ conditions (Konhauser, 2007).

Only when bacteria are present, the continuous dissolution of calcite and a synchronous formation of lepidocrocite $(\gamma-\mathrm{FeOOH})$ is visible. This shows the strong influence that $S$. putrefaciens has on dissolution-precipitation reactions of phases that are sensitive to $\mathrm{pH}$ and redox conditions in the confined volume system (calcite and lepidocrocite, respectively).

A schematic representation of the processes affecting the montmorillonite and accessory phases in the compacted MX80 bentonite is given in Fig. 10. During the initial stages of hydration the bacteria are present in pore spaces and attached to mineral surfaces (Fig. 10a). Accessory minerals such as calcite and pyrite are also present in the assemblage. With increasing hydration, micro-pores become closed and the bacteria are likely to produce EPS as a protection mechanism, e.g. against the increasing pressure. At the same time, pyrite oxidation and calcite hydrolysis releases various elements into the solution
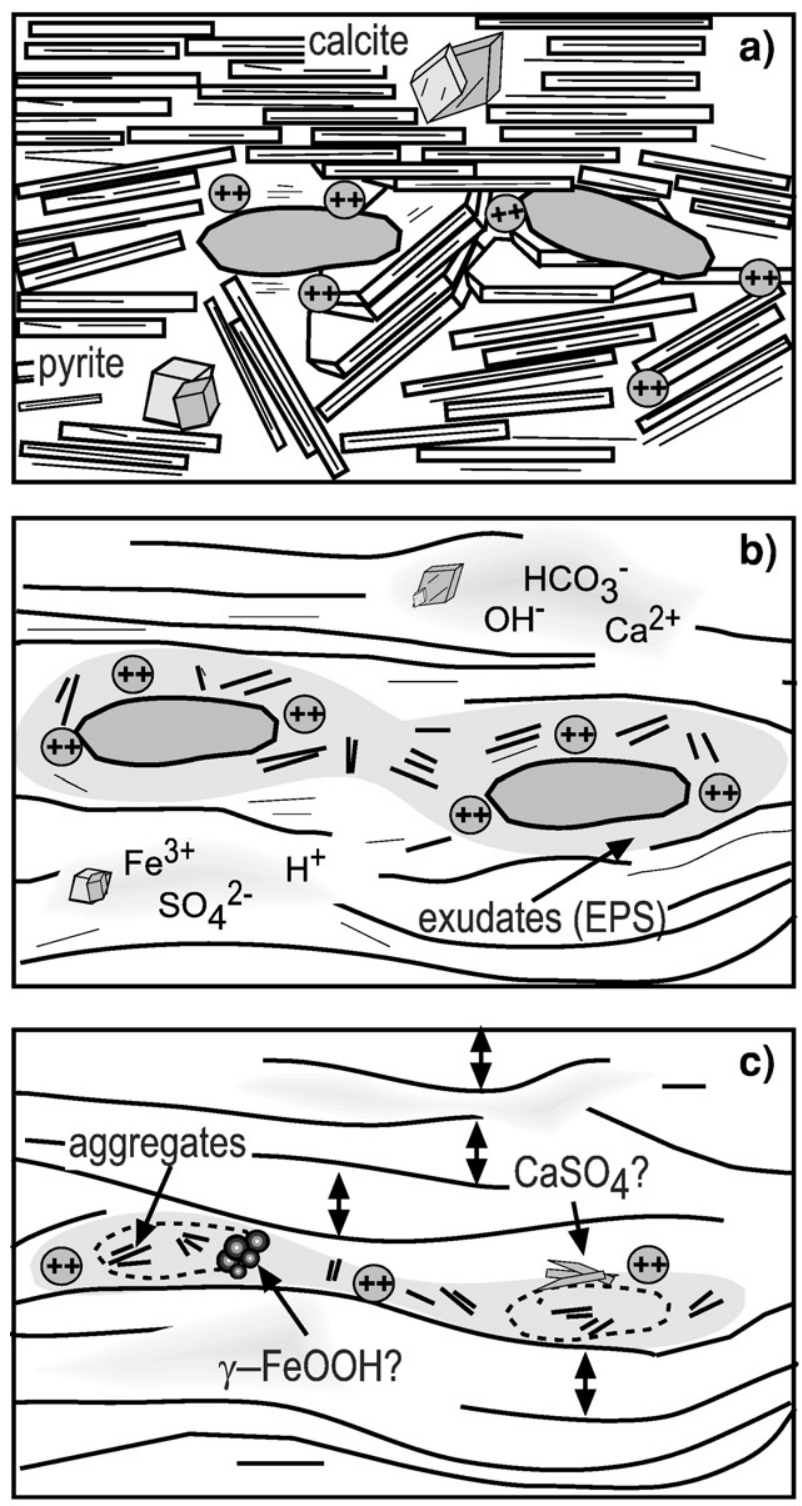

Fig. 10. Schematic model of bacteria and MX80 bentonite interaction in compacted clay under confined volume conditions. a) Directly after closing the reaction-cell, bacteria occupy pore spaces. Accessory minerals are calcite and pyrite. b) Pores are closed due to increasing montmorillonite swelling and accessory minerals dissolve. Exudates of bacteria cause formation of aggregates inducing the creation of additional space. c) After death and lyses of bacteria and the dissolution of calcite, newly formed porosity is available for additional swelling and precipitations (e.g. Lepidocrocite, $\gamma$-FeOOH). providing new space (Fig. 10b). With increasing compaction the bacteria die and lyses provides additional pore space, where remaining EPS is bound to aggregates. Redox and pH conditions may become advantageous for the precipitation of the secondary phases lepidocrocite and bassanite. Here the aggregates are suggested to serve as nucleation sites in the vicinity of EPS (Fig. 10c).

\subsection{Implications for bentonite as backfill in the disposal of nuclear waste}

The chemical alteration of pure nontronite by $S$. putrefaciens in solution is significant, especially if this smectite constitutes the only substrate. Therefore in an underground nuclear waste repository site, where Fe-rich smectite minerals may form at the interface between backfill and containers (Wilson et al., 2006a), the presence of bacteria such as $S$. putrefaciens could have significant effects on the stability of the disposal site. Such enhanced bacterial activity and chemical alteration is likely to be associated with considerable mass transfer, but only where the permeability is enhanced and alteration occurs in a solution dominated system.

It is, however, expected that the backfill in an underground repository will be a highly compacted and therefore confined volume conditions should dominate. Under such conditions, nontronite was seen to be less sensitive as compared to the MX80 bentonite, where significant textural changes were observed. Those differences are most likely controlled by smectite composition, especially the different interlayer cations. Montmorillonites containing $\mathrm{Na}$ as interlayer cations (MX80) often form gels in open pore spaces that, when aggregated, change the bulk texture. In contrast, smectites containing predominantly interlayer Ca (nontronite) do not form gels (Lagaly, 1993) and the overall texture is less affected by changing environmental factors. In the case of MX80, it has to be carefully evaluated to what extent such textural changes may lead to an increase in porosity that could provide additional pathways for transport. Our study suggests that additional porosity accommodates thicker water layers and neoprecipitations that may seal the newly formed pore space.

Generally it has to be taken into account that other bacteria, especially indigenous organisms are most likely to be more successful under confined volume conditions that $S$. putrefaciens. Recent studies by Chi Fru and Athar (2008) on indigenous organisms showed the predominance of spore-forming, gram-positive bacteria and especially those organisms are considered likely to survive even geological time spans (Fredrickson and Onstott, 1996). The microbial lineages that are considered to be most successful in a repository include Desulfosporosinus, Pseudomonas stutzeri, Bacillus megaterium, and Sedimentibacter hydroxybenzoicus, all of which are well adapted to subsurface habitats (Chi Fru and Athar, 2008). Therefore, the results with S. putrefaciens most likely underestimate the effect of bacteria on bentonite, and additional experiments with indigenous bacteria can help to further elucidate the impact of bacteria on backfill materials.

On a repository scale, bacterial activity is likely to be less significant compared to the small-scaled laboratory experiments where relatively large numbers of bacteria were introduced. Additionally, the packing density of the compressed bentonite blocks applied in a repository $\left(>1.8 \mathrm{~g} / \mathrm{cm}^{3}\right)$ will exceed the minimal packing density needed to suppress bacterial activity (Stroes-Gascoyne et al., 2007, 2008). However, it is expected that this packing density is (temporarily) not maintained at a number of interfacial environments, providing conditions more beneficial for microbial activity (Stroes-Gascoyne et al., 2008). Our experiments indicate that already limited bacterial activity in such low-packing density environments can, depending on the material, induce persistent textural changes as well as influence Eh and $\mathrm{pH}$ conditions. Therefore, the possibility of initially bacterially induced textural alteration has to be evaluated carefully in the safety assessment and a possible influence of bacteria on the Eh and $\mathrm{pH}$ in backfill materials has to be considered. 


\section{Conclusions}

Our laboratory study on S. putrefaciens interaction with nontronite and MX80 bentonite allows us to draw the following conclusions:

- Batch experiments show successful growth and prolonged survival (compared to growth media) of S. putrefaciens in MX80 bentonite (backfill material) and nontronite suspensions (simulating Fe-rich alteration product) indicating that additional survival strategies of bacteria are active (e.g. recycling of carbon, smectite as a nutrient source and partial mineral dissolution).

- The impact of bacteria on smectite present in suspensions is highly dependent on the chemical composition of the clay material. A strong impact from viable bacteria is visible on nontronite stability with metal sequestration ( $\mathrm{Fe}(\mathrm{III})$ ) by organic ligands triggering mineral dissolution. Interlayer $\mathrm{Ca}$ additionally serves as cationic bridges that facilitate the access of bacteria to suspended minerals. MX80 bentonite in contrast shows no signs of significant smectite dissolution.

- In situ reaction-cell XRD results show that bacteria have no significant impact on nontronite water content, confirming compacted clay in a confined volume restricts bacterial activity. However a recognizable influence is seen on the water balance of MX80 bentonite, which is attributable to bacterially induced textural alteration. Both the amount of interlayer water (responsible for sealing) and external surface- and pore-water is increased. This highlights the importance of quantifying all types of storage sites (including external water storage) in assessing solution storage and transport.

- Whole rock XRD of MX80 bentonite show dissolution and precipitation reactions of accessory phases indicating bacterially induced changes in $\mathrm{pH}$ and redox conditions. These reactions, in combination with bacterially induced aggregate formation and cell lyses, lead to the formation of new pore space. Additional interlayer swelling as well as neo-precipitations may contribute to a partial resealing of these newly formed pores.

- Chemical and structural changes in the compacted clay persisted at the end of the experiments although no viable cells were found. Therefore bacteria could affect the stability of backfill materials in underground waste disposal sites and their influence has to be taken into account with respect to long-term safety.

\section{Acknowledgements}

This work was supported by the French Ministry of Research (3 years PhD grant). The support from the Geoparticles Group of the CGS in Strasbourg and Christian Scholz and Margot Isenbeck-Schröter from the IUC in Heidelberg is gratefully acknowledged. We thank two anonymous reviewers for their helpful comments.

\section{References}

Akpokodje, E.G., 1984. The occurrence of bassanite in some Australian arid-zone soils Chemical Geology 47, 361-364.

ANDRA, 2005. Dossier 2005 - Argile: Évaluation de la faisabilité du stockage géologique en formation argileuse profonde - Rapport de synthèse, Décembre 2005. Andra, France (available at www.andra.fr).

Aouad, G., 2006. Influence de Pseudomonas aeruginosa sur la degradation de silicates: incidence sur la stabilite de matrices de confinement de dechets et d'un machefe industriel. Université Louis Pasteur, Strasbourg. 137 pp.

Banfield, J.F., Hamers, R.J., 1997. Processes at minerals and surfaces with relevance to microorganisms and prebiotic synthesis. Reviews in Mineralogy 35, 116-122.

Banfield, J.F., Welch, S.A., 2000. Microbial controls on the mineralogy of the environment. In: Vaughan, D.J., Wogelius, R.A. (Eds.), Environmental Mineralogy. European Mineralogical Union Notes in Mineralogy. Eotvos University Press, Budapest, pp. 173-196.

Barker, W.W., Welch, S.A., Banfield, J.F., 1997. Biogeochemical weathering of silicate minerals. Reviews in Mineralogy 35, 419-428.
Bennett, P.C., Hiebert, F.K., Choi, W.J., 1996. Microbial colonization and weathering of silicates in a petroleum-contaminated groundwater. Chemical Geology 132 (1-4), $45-53$.

Bennett, P.C., Rogers, J.R., Choi, W.J., Hiebert, F.K., 2001. Silicates, silicate weathering, and microbial ecology. Geomicrobiology Journal 18 (1), 3-19.

Bérend, I., Cases, J.M., François, M., Uriot, J.P., Michot, L., Masion, A., Thomas, F., 1995. Mechanism of adsorption and desorption of water vapor by homoionic montmorillonites: 2. The $\mathrm{Li}^{+}, \mathrm{Na}^{+}, \mathrm{K}^{+}, \mathrm{Rb}^{+}$and $\mathrm{Cs}^{+}$- exchanged forms. Clays and Clay Minerals 43 (3), 324-336.

Beveridge, T.J., 1989. Metal Ions and Bacteria. Wiley, New York. 1-29 pp.

Bickmore, B.R., Bosbach, D., Hochella Jr., M.F., Charlet, L., Rufe, E., 2001. In situ atomic microscopy study of hectorite and nontronite dissolution: implications for phyllosilicate edge surface structures and dissolution mechanisms. American Mineralogist 86 (4), 411-423.

Bosbach, D., Charlet, L., Bickmore, B., Hochella Jr., M.F., 2000. The dissolution of hectorite: in-situ, real-time observations using atomic force microscopy. American Mineralogist 85 (9), 1209-1216.

Bradley, W.F., Grim, R.E., Clark, G.F., 1937. A study of the behavior of montmorillonite on wetting. Zeitschrift für Kristallographie 97, 260-270.

Cases, J.M., Bérend, I., Besson, G., François, M., Uriot, J.P., Thomas, F., Poirier, J.E., 1992. Mechanism of adsorption and desorption of water vapor by homoionic montmorillonite. 1. The sodium-exchanged form. Langmuir 8 (11), 2730-2739.

Cases, J.M., Bérend, I., François, M., Uriot, J.P., Michot, L.J., Thomas, F., 1997. Mechanism of adsorption and desorption of water vapor by homoionic montmorillonite: 3 . The $\mathrm{Mg}^{2+}, \mathrm{Ca}^{2+}, \mathrm{Sr}^{2+}$ and $\mathrm{Ba}^{2+}$ exchanged forms. Clays and Clay Minerals 45 (1), 8-22.

Chi Fru, E., Athar, R., 2008. In situ bacterial colonization of compacted bentonite under deep geological high-level radioactive waste repository conditions. Environmental Biotechnology 79, 499-510.

Dawson, M.P., Humphrey, B.A., Marshall, K.C. 1981. Adhesion: A tactic in the survival strategy of a marine vibrio during starvation. Current Microbiology 6 (4), 195-199.

Dean, A.C.R., Hinshelwood, C.N., 1966. Growth, Function and Regulation in Bacterial Cells. Claredon Press, Oxford.

DiChristina, T.J., Arnold, R.G., Lidstrom, M.E., Hoffmann, M.R., 1988. Dissimilative iron reduction by the marine eubacterium Alteromonas putrefaciens strain 200. Water Science and Technology 20 (11-12), 69-79.

Drits, V., Srodon, J., Eberl, D.D., 1997. XRD measurement of mean crystallite thickness of illite and illite/smectite: reappraisal of the Kubler index and the Scherrer equation. Clays and Clay Minerals 45 (3), 461-475.

Drits, V.A., Eberl, D.D., Srodon, J., 1998. XRD measurement of mean thickness, thickness distribution and strain for illite and illite-smectite crystallites by the BertautWarren-Averbach technique. Clays and Clay Minerals 46 (1), 38-50.

Ehrlich, H.L., 1999. Microbes as geologic agents: their role in mineral formation. Geomicrobiology Journal 16 (2), 135-153.

Fein, J.B., Scott, S., Rivera, N., 2002. The effect of Fe on Si adsorption by Bacillus subtilis cell walls: insights into non-metabolic bacterial precipitation of silicate minerals. Chemical Geology 182 (2-4), 265-273.

Fredrickson, J.K., Onstott, T.C., 1996. Microbes deep inside the earth. Scientific American $275(4), 68-73$

Furukawa, Y., O'Reilly, S.E., 2007. Rapid precipitation of amorphous silica in experimental systems with nontronite (NAu-1) and Shewanella oneidensis MR-1. Geochimica et Cosmochimica Acta 71 (2), 363-377.

Gates, W.P., Jaunet, A.M., Tessier, D., Cole, M.A., Wilkinson, H.T., Stucki, J.W., 1998. Swelling and texture of iron-bearing smectites reduced by bacteria. Clays and Clay Minerals 46 (5), 487-497.

Gauthier, G., Gauthier, M., Christen, R., 1995. Phylogenetic analysis of the genera Alteromonas, Shewanella, and Moritella using genes coding for small-subunit rRNA sequences and division of the genus Alteromonas into two genera, Alteromonas (emended) and Pseudoalteromonas gen. nov., and proposal of twelve new species combinations. International Journal of Systematic Bacteriology 45 (4), 755-761.

Gorshkov, A.I., Drits, V.A., Dubinina, G.A., Bogdanova, O.A., Sivtsov, A.V., 1992. The role of bacterial activity in the formation of hydrothermal Fe-Mn-formations in the northern part of the Lau Basin (south-western part of the Pacific Ocean). Izvestiya Akademiya Nauk, Seriya Geologicheskaya 9, 84-93.

Hermann-Stengele, R. Plötze, M., 2000. Suitability of mineral for controlled landfill and containment. In: Vaughan, D.J., Wogelius, R.A. (Eds.), Environmental Mineralogy. European Mineralogical Union Notes in Mineralogy. Eotvos University Press, Budapest, pp. 291-331.

Hersman, L.E., Huang, A., Maurice, P.A., Forsythe, J.H., 2000. Siderophore production and iron reduction by Pseudomonas mendocina in response to iron deprivation. Geomicrobiology Journal 17 (4), 261-273.

Hofman, U., Bilke, W., 1936. Intercrystalline swelling of montmorillonite. KolloidZeitschrift 77, 239-251.

Horn, J.M., Meike, A., 1995. Microbial Activity at Yucca Mountain. Part I: Microbial Metabolism, Adaptation and Repository Environment. Lawrence Livermore National Laboratory.

Horn, J.M., Masterson, B.A., Rivera, A., Miranda, A., Davis, M.A., Martin, S., 2004. Bacterial growth dynamics, limiting factors, and community diversity in a proposed geological nuclear waste repository environment. Geomicrobiology Journal 21 (4), 273-286.

Jaisi, D.P., Dong, H., Kim, J., He, Z., Morton, J.P., 2007. Nontronite particle aggregation induced by microbial Fe(III) reduction and exopolysaccharide production. Clays and Clay Minerals 55 (1), 96-107.

Johannesson, L.E., Boegesson, L., Sanden, T., 1995. Compaction of Bentonite Blocks. TR 95-19, SKB, Stockholm, Sweden.

Kawano, M., Tomita, K., 2001. Microbial biomineralization in weathered volcanic ash deposit and formation of biogenic minerals by experimental incubation. American Mineralogist 86 (4), 400-410. 
Keeling, J.L., Raven, M.D., Gates, W.P., 2000. Geology and characterization of two hydrothermal nontronites from weathered metamorphic rocks at the Uley Graphite Mine, South Australia. Clays and Clay Minerals 48 (5), 537-548.

Kim, J., Dong, H., Seabaugh, J., Newell, S.W., Eberl, D.D., 2004. Role of microbes in the smectite-to-illite reaction. Science 303 (5659), 830-832.

Kjelleberg, S., Hermansson, M., 1984. Starvation-induced effects on bacterial surface characteristics. Applied and Environmental Microbiology 48 (3), 497-503.

Kohler, B., Singer, A., Stoffers, P., 1994. Biogenic nontronite from marine white smoker chimneys. Clays and Clay Minerals 42 (6), 689-701.

Komine, H., Ogata, N., 2004. Predicting swelling characteristics of bentonites. Journal of Geotechnical and Geoenvironmental Engineering 130 (8), 818-829.

Konhauser, K., 2007. Introduction to Geomicrobiology. Blackwell Publishing, Oxford. $425 \mathrm{pp}$.

Konhauser, K.O., Urrutia, M.M., 1999. Bacterial clay authigenesis: a common biochemical process. Chemical Geology 161, 399-413.

Kostka, J.E., Stucki, J.W., Nealson, K.H., Jun, W.U., 1996. Reduction of structural Fe(III) in smectite by a pure culture of Shewanella putrefaciens strain MR-1. Clays and Clay Minerals 44 (4), 522-529.

Kostka, J.E., Haefele, E., Viehweger, R., Stucki, J.W., 1999. Respiration and dissolution of iron(III)-containing clay minerals by bacteria. Environmental Science and Technology 33 (18), 3127-3133.

Lagaly, G., 1993. Reaktionen des Tonminerale. In: Jasmund, K., Lagaly, G. (Eds.), Tonminerale und Tone: Struktur, Eigenschaften und Einsatz in Industrie und Umwelt. Steinkopff Verlag, Darmstadt, pp. 89-167.

Lee, J.V., Gibson, D.M., Shewan, J.M., 1977. A numerical taxonomic study of some pseudomonas like marine bacteria. Journal of General Microbiology 98 (2), 439-451.

Liermann, L.J., Kalinowski, B.E., Brantley, S.L., Ferry, J.G., 2000. Role of bacterial siderophores in dissolution of hornblende. Geochimica et Cosmochimica Acta 64 (4), 587-602.

Lovley, D.R., 1991. Dissimilatory Fe(III) and Mn(IV) reduction. Microbiological Reviews 55 (2), 259-287.

Lovley, D.R., Phillips, E.J.P., Gorby, Y.A., Landa, E.R., 1991. Microbial reduction of uranium. Nature 350 (6317), 413-416.

Lovley, D.R., Phillips, E.J.P., Lonergan, D.J., 1989. Hydrogen and formate oxidation coupled to dissimilatory reduction of iron or manganese by Alteromonas putrefaciens. Applied and Environmental Microbiology 55 (3), 700-706.

MacDonell, M.T., Colwell, R.R., 1985. Phylogeny of the vibrionaceae, and recommendation for two new genera, listonella and shewanella. Systematic and Applied Microbiology 6 (2), 171-182.

MacEwan, D.M.C., Wilson, M.J., 1980. Interlayer and intercalation complexes of clay minerals. In: Brindley, G.W., Brown, G. (Eds.), Crystal structure of Clay Minerals and their X-ray Identification. Mineralogical Society, London, pp. 197-242.

Marshall, K.C., Stout, R., Mitchell, R., 1971. Selective sorption of bacteria from seawater. Canadian Journal of Microbiology 17 (11), 1413-1416.

Maurice, P.A., Warren, L.A., 2006. Introduction to Geomicrobiology: Microbial Interactions with Minerals, CMS Workshop Lectures, pp. 1-35.

Maurice, P.A., Vierkorn, M.A., Hersmann, L.E., Fulghum, J.E., 2001. Dissolution of well and poorly ordered kaolinites by an aerobic bacterium. Chemical Geology 180, 81-97.

Méring, J., 1949. L'interférence des Rayons X dans les system à stratification désordonnée. Acta Crystallographica 2, 371-377.

Morse, J.W., 1983. The kinetics of calcium carbonate dissolution and precipitation. In: Reeder, R.J. (Ed.), Carbonates: Mineralogy and Chemistry Reviews. Minerological Society of America, Washington, DC, pp. 227-264.

Myers, C.R., Nealson, K.H., 1988. Bacterial manganese reduction and growth with manganese oxide as the sole electron acceptor. Science 240 (4857), 1319-1321.

NEA, 1999. Confidence in the Evaluation of Safety Deep Geological Repositories - Its Development and Communication. OECD, Paris. 79 pp.

Nordstrom, D.K., 1982. Aqueous pyrite oxidation and the consequent formation of secondary iron minerals. In: Kittrick, J.S., Fanning, D.S., Hossner, L.R. (Eds.), Acid Sulphate Weathering. Soil Science of America Special Publication, Madison, pp. 37-56.

Obuekwe, C.O., Westlake, D.W.S., 1982. Effect of reducible compounds (potential electron acceptors) on reduction of ferric iron by Pseudomonas species. Microbios Letters 19 (74), 57-61.

OECD, 2006. Safety of geological disposal of high-level and long-lived radioactive waste in France: An International Peer Review of the Dossier 2005 Argile Concerning Disposal in the Callovo-Oxfordian Formation. OECD Papers 6, 88-164.

O'Loughlin, E.J., Larese-Casanova, P., Scherer, M., Cook, R., 2007. Green rust formation from the bioreduction of a-FeOOH (Lepidocrocite): comparison of several Shewanella species. Geomicrobiology Journal 24 (3-4), 211-230.

Omoike, A., Chorover, J., 2006. Adsorption to goethite of extracellular polymeric substances from Bacillus subtilis. Geochimica et Cosmochimica Acta 70 (4), 827-838.

O'Reilly, S.E., Furukawa, Y., Newell, S., 2006. Dissolution and microbial Fe(III) reduction of nontronite (NAu-1). Chemical Geology 235 (1-2), 1-11.

Pedersen, K., 2000. Microbial Processes in Radioactive Waste Disposal, Technical Report TR-00-04, Swedish Nuclear Fuel and Waste Management Co., Stockholm, Sweden.
Pedersen, K., Motamedi, M., Karnland, O., Sandén, T., 2000. Cultivability of microorganisms introduced into a compacted bentonite clay buffer under high-level radioactive waste repository conditions. Engineering Geology 58 (2), 149-161.

Perdrial, N., Liewig, N., Delphin, J.-E., Elsass, F., 2008. TEM evidence for intracellular accumulation of lead by bacteria in subsurface environments. Chemical Geology 253 (3-4), 196-204.

Plançon, A., Drits, V.A., 1999. Programs for Calculation of Diffraction by Oriented Powders of Two- and Three Component Mixed Layer Clay Minerals, CALCMIX (available from the authors).

Postgate, J.R., 1976. Death in Macrobes and Microbes. In: Gray, T.R.G., Postgate, J.R. (Eds), The Survival of Vegetative Microbes. Cambridge University Press, London, pp. 1-19.

Pusch, R., 2006. Chapter 11.4 clays and nuclear waste management. In: Bergaya, $\mathrm{F}$ Theng, B.K.G., Lagaly, G. (Eds.), Developments in Clay Science. Elsevier, pp. 703-716.

Rosenberg, D.R., Maurice, P.A., 2003. Siderophore adsorption to and dissolution of kaolinite at $\mathrm{pH} 3$ to 7 and $22^{\circ} \mathrm{C}$. Geochimica et Cosmochimica Acta 67 (2), 223-229.

Roszak, D.B., Colwell, R.R., 1987. Survival strategies of bacteria in the natural environment. Microbiological Reviews 51 (3), 365-379.

Saier, M.H.J., 1987. Enzymes in Metabolic Pathways. A Comparative Study of Mechanism, Structure, Evolution, and Control. Harper and Row, New York.

Sauzeat, E., Villiéras, T.F., François, M., Pelletier, M., Barrés, O., Yvon, J., Guillaume, D., Dubbessy, J., Pfeiffert, C., Ruck, R., Cathelineau, M., 2001. Caractérisation minéralogique, cristallochimique et texturale de l'argile MX-80, ANDRA Technical Report, France.

Simoni, S.F., Bosma, T.N.P., Harms, H., Zehnder, A.J.B., 2000. Bivalent cations increase both the subpopulation of adhering bacteria and their adhesion efficiency in sand columns. Environmental Science and Technology 34, 1011-1017.

Stotzky, G., 1966a. Influence of clay minerals on microorganisms. III. Effect of particle size, cation exchange capacity, and surface area on bacteria. Canadian Journal of Microbiology 12 (6), 1235-1246.

Stotzky, G., 1966b. Influence of clay minerals on microorganisms. II. Effect of various clay species, homoionic clays, and other particles on bacteria. Canadian Journal of Microbiology 12 (4), 831-848.

Stotzky, G., Rem, L.T., 1966. Influence of clay minerals on microorganisms. I. Montmorillonite and kaolinite on bacteria. Canadian Journal of Microbiology 12 (3), 547-563.

Stroes-Gascoyne, S., Hamon, C.J., Dixon, D.A., Kohle, C.L., Maak, P. 2007. The effects of dry density and porewater salinity on the physical and microbiological characteristics of compacted $100 \%$ bentonite. Materials Research Society Symposium Proceedings 985, 505-510.

Stroes-Gascoyne, S., Hamon, C.J., Maak, P., Russel, S., 2008. The effects of the physical properties of highly compacted smectite clay (bentonite) on the culturability of indigenous microorganisms. Applied Clay Science (available on journal web site).

Stucki, J.W., Kostka, J.E., 2006. Microbial reduction of iron in smectite. Comptes Rendus Geoscience 338 (6-7), 468-475.

Stucki, J.W., Komadel, P., Wilkinson, H.T., 1987. Microbial reduction of structural iron(III) in smectites. Soil Science Society of America Journal 51 (6), 1663-1665.

Van Loosdrecht, M.C.M., Lyklema, J., Norde, W., Zehnder, A.J.B., 1989. Bacterial adhesion: a physiochemical approach. Microbial Ecology 17 (1), 1-15.

Van Loosdrecht, M.C.M., Lyklema, J., Norde, W., Zehnder, A.J.B., 1990. Influence of interfaces on microbial activity. Microbiological Reviews 54 (1), 75-87.

Venkateswaran, K., Moser, D.P., Dollhopf, M.E., Lies, D.P., Saffarini, D.A., MacGregor, B.J., Ringelberg, D.B., White, D.C., Nishijima, M., Sano, H., Burghardt, J., Stackebrandt, E., Nealson, K.H., 1999. Polyphasic taxonomy of the genus Shewanella and description of Shewanella oneidensis sp. nov. International Journal of Systematic Bacteriology 49 (2), 705-724

Warr, L.N., Hofmann, H., 2003. In situ monitoring of powder reactions in percolating solution by wet-cell X-ray diffraction techniques. Journal of Applied Crystallography 36 (3 II), 948-949.

Warr, L.N., Berger, J.N., 2007. Hydration of bentonite in natural waters: application of "confined volume" wet-cell X-ray diffractometry. Physics and Chemistry of the Earth 32 (1-7), 247-258.

Wilson, J., Cressey, G., Cressey, B., Cuadros, J., Ragnarsdottir, K.V., Savage, D., Shibata, M. 2006a. The effect of iron on montmorillonite stability. (II) Experimental investigation. Geochimica et Cosmochimica Acta 70 (2), 323-336.

Wilson, J., Savage, D., Cuadros, J., Shibata, M., Ragnarsdottir, K.V., 2006b. The effect of iron on montmorillonite stability. (I) Background and thermodynamic considerations. Geochimica et Cosmochimica Acta 70, 306-322.

Wu, J., Roth, C.B., Low, P.F., 1988. Biological reduction of structural iron in sodiumnontronite. Soil Science Society of America Journal 52 (1), 295-296.

Yokoyama, T., Taguchi, S., Motomura, Y., Watanabe, K., Nakanishi, T., Aramaki, Y., Izawa, E., 2004. The effect of aluminum on the biodeposition of silica in hot spring water: chemical state of aluminum in siliceous deposits collected along the hot spring water stream of Steep Cone hot spring in Yellowstone National Park, USA. Chemical Geology 212 (3-4), 329-337. 